\title{
Emergence of Floating Offshore Wind Energy: Technology and Industry
}

\author{
Nuno Bento ${ }^{a, b}{ }^{*}$, Margarida Fontes ${ }^{c}$ \\ a DINÂMIA'CET, ISCTE-IUL \\ Av. das Forças Armadas, Edifício ISCTE, Sala 2N19, 1649-026 Lisboa, Portugal \\ b Universidade Católica Portuguesa, Departamento de Economia, Gestão e Ciências Sociais de Viseu, 3504-505 Viseu \\ *Corresponding author: Nuno.Bento@iscte.pt \\ b LNEG - Laboratório Nacional de Energia e Geologia \\ Estrada do Paço do Lumiar, 22, 1649-038 Lisboa Portugal, margarida.fontes@Ineg.pt
}

Version of September 10, 2018

\begin{abstract}
The paper investigates the construction of strategies aiming to up-scale low-carbon innovations from pilot to full commercial scale. This requires a systemic understanding of the evolution of the technology along with the organizations and infrastructures supporting its development. Technological innovation systems concepts operationalize system building processes, including the establishment of constituent elements and the performance of key innovation activities. The study surveys the national roadmaps published between 2009 and 2014 for offshore wind energy in deepwaters (more than 50 meters deep) which inform on how actors expect the system to grow, including the innovation activities crucial to achieve it. The roadmaps point to the role of guidance and legitimacy as triggers of changes in other innovation processes (knowledge creation, experimentation and so on) needed for take-off. The analysis reveals that the growth plans conveyed in the roadmaps are overly optimistic when compared with the time taken to develop offshore wind energy in fixed structures for shallow waters. Several countries have adopted supporting policies following the publication of the roadmaps, but weaknesses in crucial innovation processes (e.g. specialized skills) and external factors (e.g. crisis, regulatory approval) resulted in a delay of the first large investments. Policy should be based on realistic expectations and adequate to the phase of innovation, such as the promotion of technology-specific institutions (standards, codes, regulations and so on) in technology up-scaling. New directions for research are also provided.
\end{abstract}

Keywords: innovation system; up-scaling; roadmap; offshore wind; deepwaters.

Number of words (excluding table/figure captions and references): 12,175.

(C) 2019. This manuscript version is made available under the CC-BY-NC-ND 4.0 license http://creativecommons.org/licenses/by-nc-nd/4.0/ 


\section{Introduction}

The transition from pilot projects to full commercial scale is essential for the development of emerging innovation systems. Technologies evolve in the early years of the life-cycle and eventually standardize, which typically shifts the focus from product innovation to process innovation [1-3]. At the same time, technologies adjust to their adoption environment in the process of transition to growth [4-6]. Research shows that scaling is a common heuristic in the process of technological development [7]. Technology up-scaling typically precedes market take-off and mass commercialization of technologies, as in the case of the development of onshore wind energy [8]. It requires some degree of institutionalization, namely agreement among the actors on the anticipation of the future of both the technology and markets. This is particularly relevant in the mitigation of climate change, as efforts to avoid catastrophic consequences call for the implementation of lowcarbon innovations [9].

Offshore wind energy in floating platforms is a new technology that promises to unlock a huge resource potential in deepwaters, i.e., water depths of 50 meters or higher [10-11]. Floating offshore wind is more than a simple extension of the offshore wind industry, constituting a new technology on its own right. It develops under a different environment that is marked by a specific sectoral, technological, geographical and political context. The technology presents a high potential to reduce emissions in the electricity sector, but currently deals with a number of technological and institutional challenges that prevent its market take-off [10,12-13].

The take-off of diffusion requires a minimum agreement on norms and standards that involves the prior formulation of collective expectations and visions. This process is addressed by the technological innovation systems (TIS) literature, which conceptualizes the conditions for the establishment of a new industry that provides a supportive system around the new technology [1415]. In this vein, the take-off of technological innovation systems depends on the establishment of structural elements including a network of actors and institutions [14]. In addition, TIS studies highlight the importance of key innovation processes (the so-called system functions) in the transition to growth. For example, the fulfillment of functions like legitimation and influence in the direction of search can help the formation of a collective strategy with positive effects for the mobilization of resources, the formation of demand, and the acquisition of political strength [16-17]. In particular, instruments like roadmaps contribute to shape collective expectations and to establish technology legitimacy [18].

Roadmaps are well-known tools that support technology management and planning [19-21]. They have been increasingly used in the framework of renewable energy technologies [22]. Roadmaps convey a collective vision and strategy that may influence the direction of search and thus the governance of the system transition [18]. They are particularly helpful in the early years of random patterns by enabling technology pioneers to run "in packs with others to create new relationships and institutions for collective survival" (Van de Ven [23]: 40).

Roadmaps are the result of a negotiation process that leads to a compromise between different anticipations of the future. They have the character of anticipatory coordination [24] by reducing the risk and uncertainty in technology growth. However, the compromise may reflect not only the differences in visions among the participant actors, but also their discursive power (capacity to frame an innovation), ideology and political cultures [25]. In spite of this limitation, roadmaps provide a valuable setting to examine the perspectives and proposals that prepare system development. 
This research seeks to understand the pathways of development of floating offshore wind energy and its associated innovation system, with a view to answer the following questions: how do innovation systems around emerging technologies, such as floating offshore wind, prepare for takeoff?; what are the visions that guide the up-scaling of this technological innovation system?; and how do the mechanisms that lead to the acceleration of a system's growth unfold? For that, we analyze roadmaps as instruments that enable the understanding of the process of the formation of visions and guidelines that promote the dissemination of the innovation system around this new energy technology.

The paper is organized as follows. Section 2 reviews the literature on the acceleration of the growth of innovations systems being formed around new technologies. Section 3 explains the methodology followed to study the roadmaps published on floating offshore wind energy. Section 4 presents the results of the roadmaps analysis. The concluding section summarizes the findings and discusses their implications for the policy and the literature.

\section{Construction of technological innovation systems}

Emerging innovations take time to "change gears" and accelerate the take-off $[6,26]$. A complex environment (actors, and institutions) is necessary to support the development of new energy technologies. Technological innovation systems (TIS) theory $[12,19]$ assesses the challenges faced in the construction of such environments, particularly in terms of the establishment of the system structure and functions [26-27]. To understand the underlying processes, this approach is complemented with insights from industrial and technology life-cycle literatures (e.g. [2]) and from the literature that conceptualize roadmaps as instruments to promote systems emergence (e.g. [20]).

\subsection{Structure and functions}

Technological innovation systems (TIS) scholars conceive innovation as an interactive process involving actors (e.g., firms, users) and networks acting under a particular context of institutions and policies [28]. In these terms, the emergence of a new TIS involves the establishment of structural components - i.e. technology, actors, networks and institutions - dedicated to the focal TIS or shared with other existing TISs [29]. Technology is a key element of the TIS structure, including both artefacts and knowledge [30]. Actors comprise individuals and organizations (e.g. firms) along the value chain. Networks are links established between actors to perform a given task (e.g. knowledge development and diffusion, political lobby). Institutions encompass formal rules (e.g. laws and property rights, codes and standards) and informal norms (e.g. tradition and culture) that structure social, economic and technological interactions [31-32].

In addition to these structural components, TIS scholars have increasingly looked the performance of key innovation processes (the so-called "functions") that are needed for the growth of innovation systems (Figure 1). A number of functions have been identified in two seminal papers [26-27]: development of formal knowledge, entrepreneurial experimentation, materialization; market 
formation; resource mobilization; development of positive externalities; legitimation; and influence in the direction of search $[27,30] .^{1}$

Development of formal knowledge refers to the way knowledge is created, combined, codified and shared, to form the scientific and technological base that allows the innovation to progress $[26,28]$. Entrepreneurial experimentation refers to the development of more applied, tacit and exploratory knowledge through risk-taking "entrepreneurial" actions, namely to the experimentation of a diversity of designs under a dynamic environment [23]. Materialization designates the early investment in capital stock or artefacts, including factories and infrastructures. Market formation refers to the creation of demand around increasingly organized markets, from pilot projects to niches and bridging markets. Early demand opens crucial opportunities for learning, while reducing perceived risks in the adoption by consumers [33]. Resource mobilization points to the need to attract human capital, financial capital and complementary assets from other sectors to gear up innovation systems. Development of positive externalities refers to the strengthening of the system and the dynamics of growth, comprising the capacity to take advantage of spillovers from the fulfillment of system functions, as well as from the structures and resources extant in other TISs to accelerate growth [30].

Legitimation involves social acceptance and compliance with the institutions concerned [30]. The creation of legitimacy is a socio-political process by which expectations are formed and shaped in favor of the technology [34]. Technology legitimacy is also a matter of conformity with the institutional structures of the context [35]. New technologies, particularly, have to overcome the "liability of newness" in a process that is often surrounded by the competition from established technologies [36]. By affecting actor's perceptions, legitimation also indirectly influences their strategies and thus the direction of search [26].

Influence on the direction of search reflects the mechanisms that persuade actors new to the TIS to allocate innovation activities and investments between competing technologies and designs. This includes the combined effect of two factors [26]: visions, beliefs and expectations about growth potential; and the actor's perceptions of the relative advantage of the technology from indicators that include incentives and regulation [21].

Influence on the direction of search (or guidance) can be particularly important to accelerate the take-off of emerging systems given its role in attracting new actors and mobilizing resources $[30,37,38]$.

\footnotetext{
${ }^{1}$ The rest of the presentation adopts the list of functions as described in Bergek et al. [26,30]. A group of researchers from Utrecht University has developed an alternative list of functions with slight changes to the previous one [27]: entrepreneurial activities; knowledge development; knowledge diffusion through networks; guidance of search; market formation; resource mobilization, and creation of legitimacy.
} 
Figure 1 - Basic components of the technological innovation systems approach (Source: authors' elaboration from [26-27,30,39])

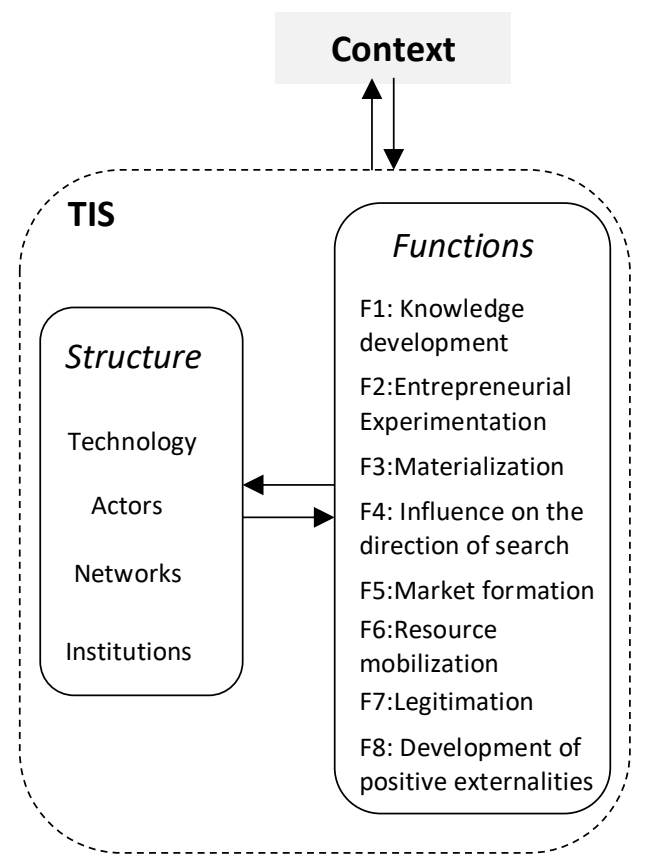

\subsection{Planning and deployment}

The creation of visions and plans for the technology is often an instrument to accelerate the growth of innovation systems. Technology roadmaps, in particular, are popular instruments for mapping industry emergence that have been used in new technology-intensive sectors to support strategy and decision making in innovation processes $[40,20,41]$. Such mapping is regarded as a basis for understanding the dynamics of the system and for acting upon those dynamics. In particular, roadmaps might be able to identify focal points for action and make decisions regarding the most adequate strategies according to the stage of development of the technological system [20].

Roadmaps set out a vision of the future and identify needs and actions to be performed, at different levels, in order to fulfill it. They are the result of a process (more or less inclusive) that attempts to reach a consensus among key actors about the future development of the technology, what they expect to happen and the paths that should be followed to achieve it [18]. In other words, roadmaps reflect the actors' view on how to "change gears" and accelerate the development of the technology. Therefore they are good indicators (although partial) of the way actors perceive and prepare system growth.

The development of roadmaps can follow certain guidelines. Phaal et al. [20] suggest a framework for mapping industry emergence grounded in technology lifecycle and evolutionary theories. The authors identified common patterns in the emergence of 25 innovations (Figure 2), including four phases (precursor, embryonic, nurture, growth) and periods of transition between them that are marked by key events, which they labelled "demonstrators". The demonstrators are milestones in the innovation process and thus should be focal points for strategy development and goal setting, such as: 
- "technology demonstrators" showing the feasibility of the underlying science (i.e. science to technology transition) from precursor to embryonic phase;

- "commercial application demonstrators" demonstrating the potential for revenue generation (i.e. technology to application transition) from embryonic to nurture phase; and

- "mass market demonstrators" displaying the economic advantages and the market potential of the technology (i.e. application to market transition) from nurture to growth phase.

Different innovation activities contribute to progress the technology along the stages. These activities range from the development of science and technology knowledge in the initial stage (through the study of the underlying phenomena and the development of prototypes), to the construction of increasingly better large scale demonstrators (in terms of the relation price/performance) in a more advanced stage. However, while private actors have weak incentives to invest in early large scale demonstrators to overcome the "valley of death," governments have a poor track record in financing large demonstrations (technology pork barrel, i.e. picking the wrong winners promoted by vested interests) and therefore decisions at this level need to be carefully balanced [42]. In practice, the innovation process is not linear but marked by feedbacks between stages, like the performance of R\&D to solve problems encountered in demonstrations. Hence there is the need to up-scale iteratively with the preoccupation of implying the private sector, prioritizing learning and the dissemination of knowledge, and creating the conditions for a solid demand growth [42].

Other frameworks include the "technology readiness level" (TRL) developed by NASA [43] which has been intensively applied in the aerospace, defense and energy sectors. TRL assesses the progression of individual technologies through a 9-point scale, ranging from "basic principles observed and reported" (TRL 1) to "actual system flight proven through successful mission operations". Comparing to the TRL, Phaal's et al. [20] framework considers the development of more complex technologies (including various components). However, it still overlooks developments in the complementary components of the system. Therefore, the TIS theory can complement this approach by supporting the assessment of the challenges occurring at a more systemic level. These include the organization of the value-chain for scaling up, or the promotion of a more favorable public opinion to stimulate demand and lower the perceived risk of investments. 
Figure 2 - Systemic representation of the innovation process and overview of activities relevant for roadmapping (Adapted from [20])

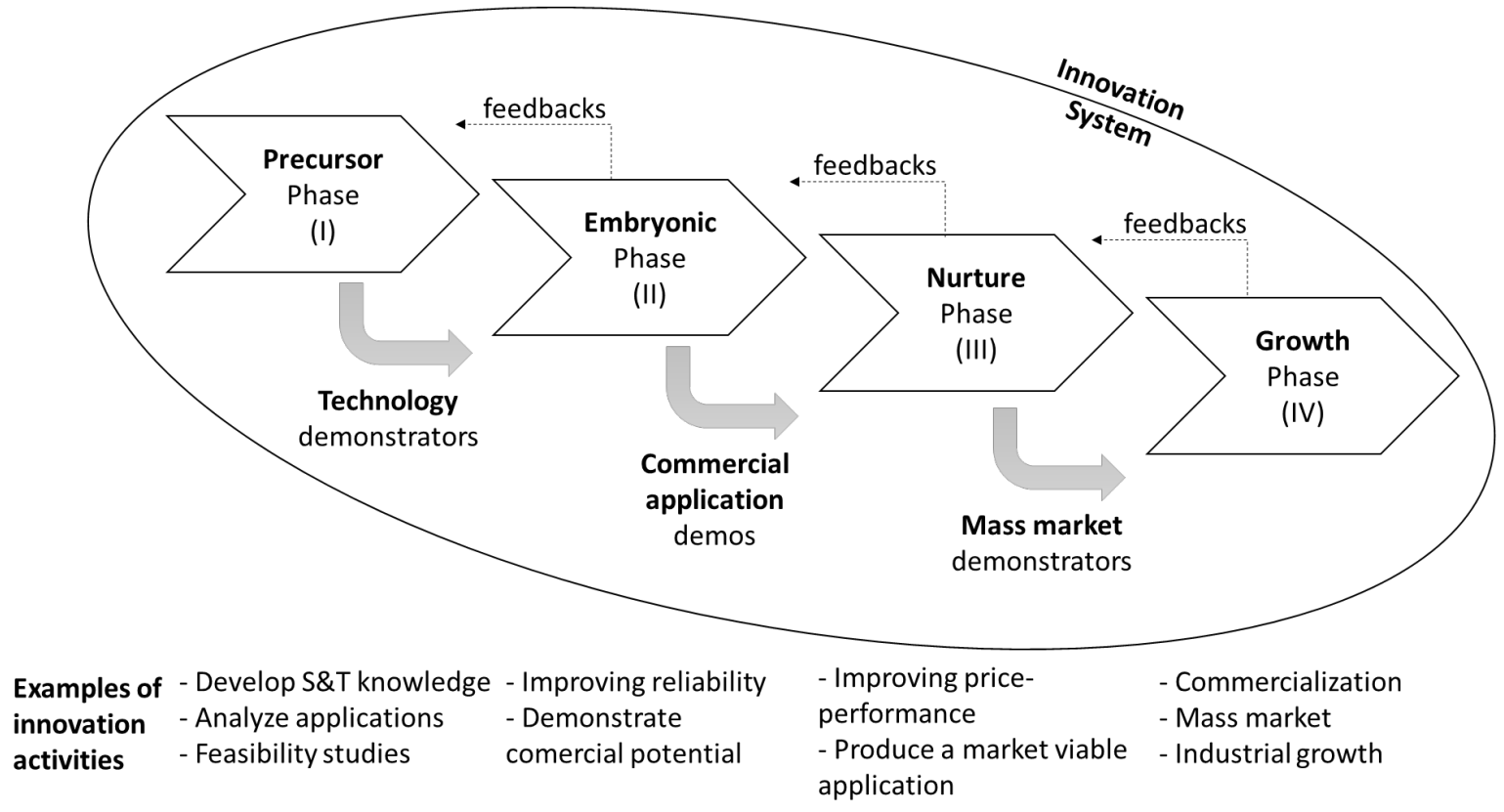

\subsection{System change}

To examine the conditions for technology up-scaling, it is necessary to understand the process of development of the system elements, such as organizations and institutions, being formed around the technology. The TIS literature conceptualizes the dynamics of innovation systems in terms of the comparison of the state of the system at different stages of development. Bergek et al. [26] distinguish between a formative phase when "...constituent elements of the new TIS begin to be put into place, involving entry of some firms and other organizations, the beginning of an institutional alignment and formation of networks" (idem: 419) and a growth phase when "... the focus shifts to system expansion and large-scale technology diffusion through the formation of bridging markets and subsequently mass markets..." (idem: 420).

A number of changes occur across the stages of development, which permit to understand the system dynamics [6]. Along this process, the system present assumes different characteristics at the level of the technology, structural elements and system functions.

Technology follows temporal patterns that have been analyzed in Section 2.2. It typically evolves from a diversity of ideas and concepts to a series of demonstrators with improved quality and lower costs, before becoming a fully mass marketed product [20]. The lifecycle literature underlines the change in the dynamics of innovation that occurs with the emergence of a dominant design, shifting from product innovation to more incremental change [1-2,44]. However, empirical studies have also shown evidence of alternative patterns of innovation with little or no decline of product innovation across the technology lifecycle in the case of more complex products and systems $[3,45]$.

Structural components become established over time to include a diversity of actors, organizations and institutions. Actors and organizations evolve from a small number of elements in the early years 
(mainly organized around networks of knowledge creation and R\&D), to a gradually more structured system composed of a larger, more diversified, network of actors [6]. Institutional structures evolve from initial visions and collective expectations (cognitive structures), to more informal and formal types of technology-specific institutions, such as technology designs (normative structures) and standards (regulatory structures) [6]. Institutions consolidate, enhancing the degree of structuration of the system around the technology that comprises "the build-up of value chains, formation of markets, development of educational programs, alignment of regulatory structures, etc." (Markard and Hekkert [46]: 7). During this process, complementarities are created between several system components including technology, institutions and infrastructures. These contextual structures can take long to materialize and need proper planning horizons to accompany the development of the focal TIS and avoid creating bottlenecks [47]. At the end, a "mature" TIS presents a high degree of structuration around a standardized mass-commercialized product, established networks and stable institutions.

Finally, the system functions also evolve over time. Key functions change, from knowledge creation and legitimation in initial years to market formation and resource mobilization with the approximation of the growth stage $[6,26]$. The fulfillment of these functions could lead to virtuous cycles that affect each other and accelerate the system's growth [48]. Hekkert et al. ([27], p.426) finds evidence that "functions positively interact and influence each other" in what is "a necessary condition for structural change". Many patterns of interaction are possible. The literature documents some patterns ("motors of change") that are associated with the successful buildup of technological innovation systems, in which a small set of system functions effectively pull other functions $[27,38]$.

A typical starter of these positive feedbacks is guidance of search (Function 4) promoted by leading actors like governments that identify societal problems and set goals to address them. This triggers the mobilization of resources (F6) for knowledge development (F1) in a "science and technology push motor".

Other positive feedback starter is entrepreneurial activities (F2) "entrepreneurial motor" that cultivate high expectations and lobby for an increasing investment in R\&D (F1) and early infrastructures (F3). Once the number of actors involved in the development and production of a technology increase, they can lobby for overcoming the resistance of incumbent actors with vested interest (F7) and for market formation (F5) in a "system building motor".

Finally, the emergence of the first markets often prompts the renewal of entrepreneurial activities (F2) that further stimulate expectations. Growing expectations drive lobbying for more investment in science and technology knowledge (F1), larger scale experimentations (F2) and policy support (F7) to market formation (F5) capable to develop production capacity (F3) in a typical "market-oriented growth motor".

Figure 3 illustrates the evolution of the technological innovation system as a succession of the four motors of innovation, as suggested in Grubler et al. [49]. The construction of a technological innovation system can be measured by the number of actors, the complexity of the network of actors and the number of technology-specific institutions. The growth of the innovation system precedes the S-shaped curve which represents diffusion creating the conditions for technology upscale [8]. The system functions (represented with circles) and the interactions between them (represented with arrows) intensify through the formative precursor and embryonic phases (I-II) that prepare the introduction of the technology into the market (III) and the acceleration of take-off (IV) that lead to system growth. 
Figure 3 - Stylized representation of the buildup of a technological innovation system (top) alongside a technology diffusion (bottom), including the system functions (circles) and their interactions (arrows). (adapted from [49]).

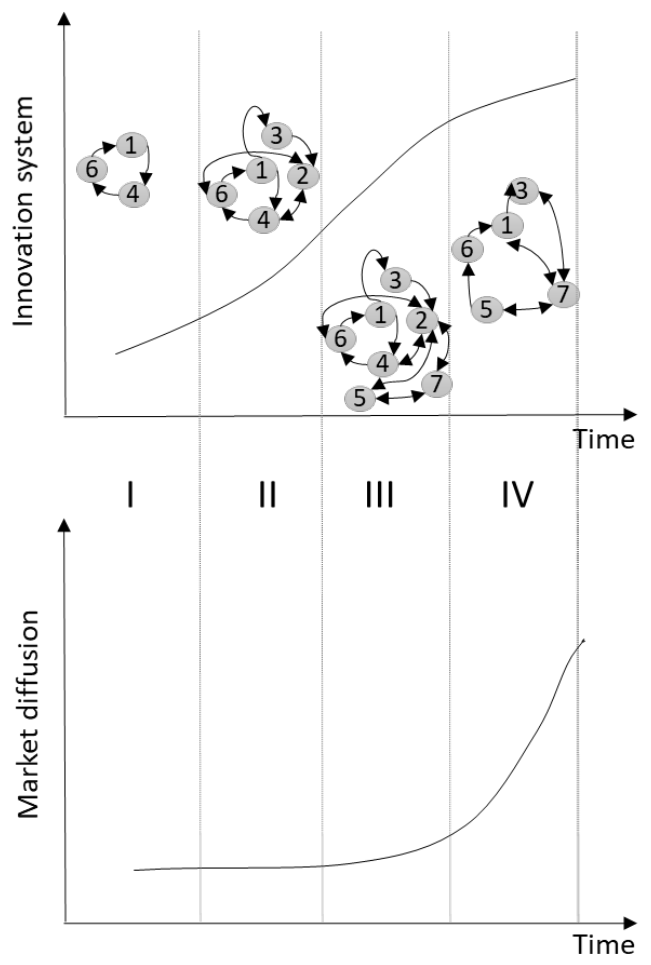

According to these approaches, entering into a process of up-scaling (to accelerate market diffusion) involves changes in several dimensions. In the case of energy technologies like offshore wind energy further progress depends on the mobilization of specialized human resources and financial capital, formation of markets and investment in infrastructure and grid connection $[13,50]$. This example shows how important is to coordinate strategies between private and public actors for system upscaling, namely through the process of roadmapping.

\section{Methodological issues}

\subsection{Research question and hypothesis}

This research seeks to improve the understanding about the process of planning the up-scaling of new sustainable energy technologies such as offshore wind in deepwaters or "floating". For that, we examine the processes undergone in the preparation for technology up-scaling, the formulation of visions by the actors and the extent to which these orientations are consistent with what could be anticipated from the literature and from the historical evidence on the growth of similar energy innovations.

Drawing on the insights from the literature, we advance the following hypotheses concerning the acceleration of technological development: 
(i) roadmaps are an element in the process of formation (legitimation) and sharing (guidance) of collective expectations;

(ii) being an instrument to convince internal and external actors that a given strategy is appropriate, right and desirable, roadmaps have a role in making expectations performative, i.e. co-production of statements and reality (see also [51-52]);

(iii) the performance of legitimation and guidance can accelerate the dynamics of growth through their impact on other innovation processes crucial for technology up-scaling, such as resource mobilization and market formation.

In these terms, roadmaps provide a helpful analytical tool to examine the perspectives and proposals for preparing the system development, with the purpose of understanding the conditions that support technology up-scaling.

Figure 4 schematically shows our analytical framework. Technology up-scaling consists of the transition from trials with small applications to larger experiments which can serve large markets. Actors and networks set their visions in roadmaps which, through their effect in guidance and legitimation - under a particular set of institutions - affect the way innovation processes needed for the up-scaling are performed.

Figure 4 - Analytical framework

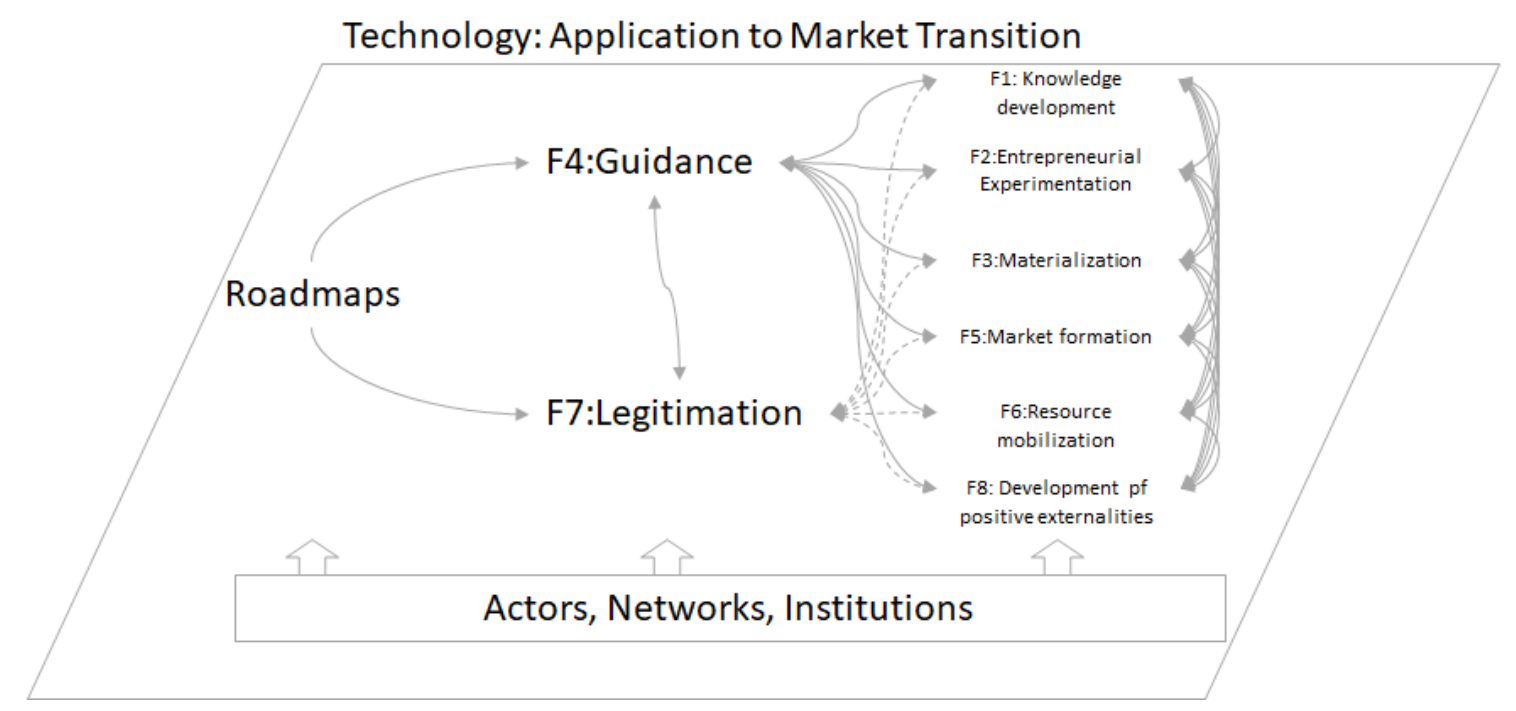

\subsection{Empirical setting and method}

The development of offshore wind energy in deepwaters - more than 50 meters deep, where most of the potential is located but whose technology is more immature - provides the empirical background for the discussion about the preparation for up-scaling.

The definition of the boundaries of the system is very important to understand what is newly emerging in the wind energy industry. Studies have shown that offshore wind energy and onshore wind energy are two clearly separated TISs, namely having a different supply chain [53]. Floating offshore wind energy is more than a simple part of the offshore wind technological innovation system and constitutes a TIS on its own right. First, the supply chain (including competencies) 
required to develop wind energy farms in deepwaters is different from the one in shallow waters in the near-shore [54]. Second, the technologies are also different, especially in what concerns the foundations (fixed versus floating structures) and the structure of costs - marked by a higher weight of initial investments in production costs [55]. Thirdly, the countries that have been involved in the development of this technology are not the same as for the offshore wind in shallow waters [56]. They have in common large wind resources potential that are located in deep waters relatively close to shore (e.g. Norway, Japan and Portugal). Finally, floating offshore wind tends to have lower environmental impacts and lower interference with other activities than installations onshore or in the near-shore and, in consequence, may face less public resistance.

The paper applies system theories like TIS [14,26-27] to track the processes of structuration (e.g. creation of value-chains) of technological innovation systems that enter into the up-scaling stage. Hence, the analysis focuses on the requirements for up-scaling in terms of changes in technology, actors, networks and institutions, at a more structural level, as well as on core innovation activities or functions, such as guidance and legitimacy, at a more functional level.

To understand how these structural and functional elements unfold, we analyze roadmaps and equivalent national programs for floating offshore wind energy, as an analytical tool. Roadmaps often provide a diagnosis of the state of the art of the technology, as well as an identification of the main system players and emerging networks. They can also be an element in the process of formation and sharing of expectations, and thus an important instrument for the performance of system functions like influence in the direction of search and legitimation, as it will be tested.

We compiled data from technological plans and roadmaps and organized them with the help of the typology of phases, transitions and key events (e.g. "demonstrators") proposed by Phaal et al. [20]. In the absence of a national development strategy, technology-based plans of key actors are analyzed instead. This procedure allows us to situate the technology in the innovation process - though acknowledging the non-linearity of this process - as well as to perform a comparative analysis of the strategies followed in different countries. Roadmaps also offer indications on the changes foreseen in the structural elements of the system (actors, networks and institutions) and on the strategies to perform the system functions, as argued above. The relevant information is extracted from the documents following a specifically created framework to analyze roadmaps for floating offshore wind energy, which is presented in Appendix 1.

The work is therefore based on the examination of the extant literature, in desk research, as well as on empirical research supported by documentary data. Table 1 lists the roadmaps (or equivalent documents) used in the analysis, encompassing 10 documents from 6 countries, ranging from 2009 to 2014. The data extracted from the individual roadmaps, following the analytical framework devised, is presented in a separate report [57]. The analysis is complemented with data from a variety of secondary sources. A non-exhaustive list includes official statistics, companies' press releases and other documentary sources such as websites or presentations at events. 
Table 1 - Roadmaps and equivalent documents analyzed

\begin{tabular}{|c|c|c|c|c|c|}
\hline Document & Country & Date & Type & Initiative & Code \\
\hline $\begin{array}{l}\text { Target \& roadmap for Japanese wind power } \\
\text { [58] }\end{array}$ & Japan & 2014 & Roadmap & $\begin{array}{l}\text { Wind Power } \\
\text { Association }\end{array}$ & JA14 \\
\hline $\begin{array}{l}\text { Demowfloat - Demonstration of the } \\
\text { WindFloat Technology Roadmap (Windplus) } \\
\text { [59] }\end{array}$ & Portugal & 2014 & $\begin{array}{l}\text { Project } \\
\text { report }\end{array}$ & $\begin{array}{l}\text { Organizational } \\
\text { (companies) }\end{array}$ & P014P \\
\hline $\begin{array}{l}\text { Technological Roadmap by the Technological } \\
\text { Observatory for the Offshore Energies [60] }\end{array}$ & Portugal & 2014 & Roadmap & $\begin{array}{l}\text { Coalition of } \\
\text { stakeholders }\end{array}$ & P014R \\
\hline $\begin{array}{l}\text { UK Renewable Energy Roadmap Update } 2013 \\
\text { [61] }\end{array}$ & UK & 2013 & Roadmap & Government & UK13R \\
\hline $\begin{array}{l}\text { Industrial Strategy: government and industry } \\
\text { in partnership [62] }\end{array}$ & UK & 2013 & $\begin{array}{l}\text { Action plan/ } \\
\text { Strategy }\end{array}$ & Government & UK13S \\
\hline $\begin{array}{l}\text { Rapport de la mission d'étude sur les énergies } \\
\text { marines renouvelables [63] }\end{array}$ & France & 2013 & $\begin{array}{l}\text { Strategy/ } \\
\text { Roadmap }\end{array}$ & $\begin{array}{l}\text { Government } \\
\text { (mission report) }\end{array}$ & FR13 \\
\hline $\begin{array}{l}\text { A National Offshore Wind Strategy: Creating } \\
\text { an Offshore Wind Energy Industry in the US } \\
\text { [64] }\end{array}$ & US & 2011 & National plan & Government & US11 \\
\hline $\begin{array}{l}\text { Offshore Renewable Energy Strategic Action } \\
\text { Plan 2012-2020 [65] }\end{array}$ & $\begin{array}{l}\text { Northern } \\
\text { Ireland }\end{array}$ & 2012 & $\begin{array}{l}\text { Action plan/ } \\
\text { Strategy }\end{array}$ & Government & $\mathrm{N} I 12$ \\
\hline UK Renewable Energy Roadmap [66] & UK & 2011 & Roadmap & Government & UK11R \\
\hline $\begin{array}{l}\text { Concerning an Act on Offshore Renewable } \\
\text { Energy Production (the Offshore Energy Act) } \\
\text { [67] }\end{array}$ & Norway & 2009 & $\begin{array}{l}\text { Strategy } \\
\text { (legislative) }\end{array}$ & Government & NO09 \\
\hline
\end{tabular}

\section{Results}

In this section we apply the framework described above to analyze roadmaps in order to uncover the projected changes to the technology, the structure and the functions of the innovation system.

\subsection{Technology}

\subsubsection{The evolution of floating offshore wind energy}

The emergence of offshore wind in deepwaters occurs in a dynamic context for wind energy in the more shallow waters. Offshore wind energy is rapidly growing in Europe with more than $8 \mathrm{GW}$ installed and $41 \mathrm{GW}$ projected by 2020 (Figure 5). More than half of the new capacity is expected to be installed in the United Kingdom and Germany, consolidating the leadership of these countries. The European Wind Energy Association [68] suggests that the capacity could reach 150 GW by 2030, meeting $14 \%$ of the EU's final electricity consumption. Asian countries have also been active in offshore wind, with China currently having over $1.5 \mathrm{GW}$ and planning $10 \mathrm{GW}$ more by 2020 [69-70]. Japan has already installed $50 \mathrm{MW}$, including $4 \mathrm{MW}$ of floating turbines. The Japan Wind Power 
Association [58] optimistically forecasts $700 \mathrm{MW}$ by 2020, of which $100 \mathrm{MW}$ in deepwaters. Korea and Taiwan have capacity targets for the coming years as well. The US has no offshore wind farms so far, but has announced plans to build $3 \mathrm{MW}$ of floating offshore wind by 2020 [72]. According to the U.S. Department of Energy's (DOE's) "Wind Vision" (central) scenario, this number should raise to $22 \mathrm{GW}$ by 2030 and $86 \mathrm{GW}$ by 2050 , contributing to the $404 \mathrm{GW}$ of wind energy forecasted to be installed by that time [73]. Table 2 summarizes the offshore wind resources for the main regions and countries investing in offshore wind energy, highlighting the high potential of Europe $(2700 \mathrm{GW}$ of assessed technical potential) and the US (2085 GW). It also signals opportunities for installations in a wide range of water depths and distances, from very close to the land (e.g. up to $30 \mathrm{~km}$ from shore in Japan) to greater distances from shore (e.g. up to $370 \mathrm{~km}$ for the US or to the limit of exclusive zones for Europe). In some cases there is the explicit consideration of floating systems (e.g. $370 \mathrm{GW}$ foreseen for Japan).

Table 2 - Characteristics of location and of wind resources offshore in the main markets

\begin{tabular}{|c|c|c|c|c|}
\hline & European Union & United States & Japan & China \\
\hline $\begin{array}{l}\text { Assessed technical } \\
\text { potential }\end{array}$ & $2700 \mathrm{GW}$ & $2085 \mathrm{GW}$ & $\begin{array}{l}156 \text { GW (fixed) / } 300 \\
\text { GW (floating) }\end{array}$ & $\begin{array}{l}200 \mathrm{GW} \text { (close } \\
\text { shore) / } 500 \mathrm{GW} \\
\text { (near offshore) }\end{array}$ \\
\hline Distance from shore & $\begin{array}{l}\text { Starting } 10 \mathrm{~km} \text { from } \\
\text { shore to the limit of } \\
\text { economic exclusive } \\
\text { zones }\end{array}$ & $\begin{array}{l}\text { Up to } 370 \mathrm{~km} \text { from } \\
\text { shore }\end{array}$ & $\begin{array}{l}\text { Up to } 30 \mathrm{~km} \text { from } \\
\text { shore }\end{array}$ & Not stated \\
\hline Water depth & $\begin{array}{l}1000 \mathrm{~m} \text { (70 m for } \\
\text { Baltic Sea) }\end{array}$ & $\begin{array}{l}1000 \mathrm{~m} \text { ( } 60 \mathrm{~m} \text { for } \\
\text { Great Lakes) }\end{array}$ & Up to $200 \mathrm{~m}$ & $5-25 \mathrm{~m} / 5-50 \mathrm{~m}$ \\
\hline Height of turbine & $100 \mathrm{~m}$ & $100 \mathrm{~m}$ & $80 \mathrm{~m}$ & $100 \mathrm{~m}$ \\
\hline Wind speed & $>8 \mathrm{~m} / \mathrm{s}$ & $>7 \mathrm{~m} / \mathrm{s}$ & $>7 \mathrm{~m} / \mathrm{s} / 7.5 \mathrm{~m} / \mathrm{s}$ & Not stated \\
\hline Exclusions & $\begin{array}{l}\text { Areas with } \\
\text { conflicting uses or } \\
\text { environmental } \\
\text { concerns }\end{array}$ & $\begin{array}{l}\text { Areas with } \\
\text { conflicting uses or } \\
\text { environmental } \\
\text { concerns }\end{array}$ & $\begin{array}{l}\text { Areas with conflicting } \\
\text { uses (e.g. fishing) or } \\
\text { environmental } \\
\text { concerns }\end{array}$ & $\begin{array}{l}\text { Areas with } \\
\text { conflicting uses or } \\
\text { environmental } \\
\text { concerns }\end{array}$ \\
\hline
\end{tabular}

Notes: $\mathrm{GW}=$ gigawatt; $\mathrm{km}=$ kilometers; $\mathrm{m}=$ meters; $\mathrm{m} / \mathrm{s}=$ meters per second.

Sources: IEA [74], WindEurope [75]; NREL [76], JWPA [58], Li, et al. [77], IEA [70].

The dynamics of the offshore wind energy have been summarized by Rodrigues et al. (2015 [54], p.1132) as follows: "...the initial OWPs [offshore wind projects] mostly served as proof of concept. Hence, they were located in shallow waters close to shore and were composed of few wind turbines leading to low investment costs which were highly dependent on the number of turbines. Nowadays, commercial projects have higher installed capacities, are highly capital intensive and more complex to design, due to the larger seabed areas, higher number of turbines and longer distances to shore."

The average water depth and distance to shore have been increasing over time. The maximum water depth is increasing at a pace well represented by a logistic fit with the inflection point in 2012 and saturation of 164 meters, as presented in Figure 6. Figure 7 shows that new offshore wind farms are installed in in deeper waters (comparing the trend in 2016 with 2017) and further away from shore (comparing with 2015). Higher distances to shore correlate with higher mean wind speeds and greater capacity factors [54]. Capacity factors are expected to jump from $40 \%$ to $50-60 \%$ in the medium term [74], easing intermittency problems of wind energy [78]. However, the water depths tend to increase with the distance to shore, driving up installation and foundation costs, as well as operational and maintenance costs [55]. Most future wind farms are likely to remain at a maximum 
depth of 50 meters, but there are still a significant number of projects expected for higher depths. This especially concerns countries that have deepwaters relatively close to the shore, such as Portugal, Norway or Italy. To exploit the huge potential in the deepwaters, a number of technologies are necessary, such as floating support structures, which are still in the pre-commercial stage.

Figure 5 - Installed capacity and generation potential of offshore wind energy (both historically and projected) up to 2020, by Member State, as described in the National Renewable Energy Action Plans (NREAPs)

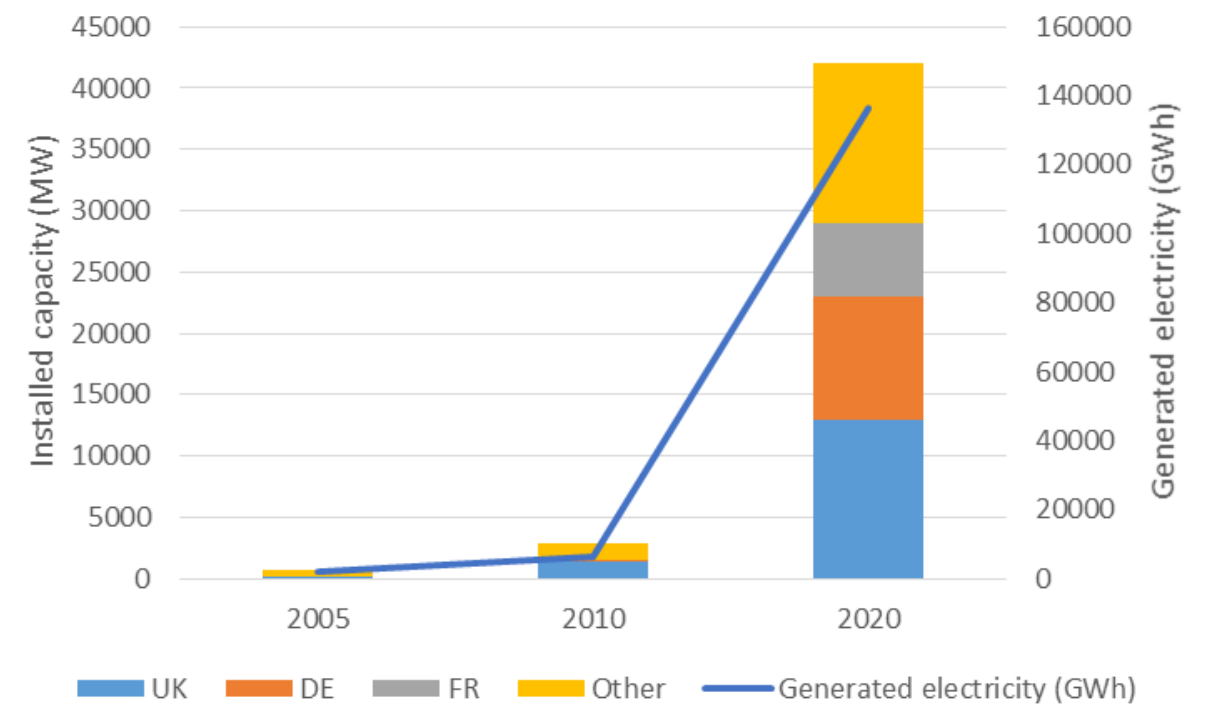

Source: European Commission [11], from information in the NREAPs.

Figure 6 - Maximum mean water depth of extant and planned European offshore wind farms (logistic fit with inflection point in 2012, speed (delta t) of 20 years and saturation in 164 meters, $R^{2}=79 \%$ )

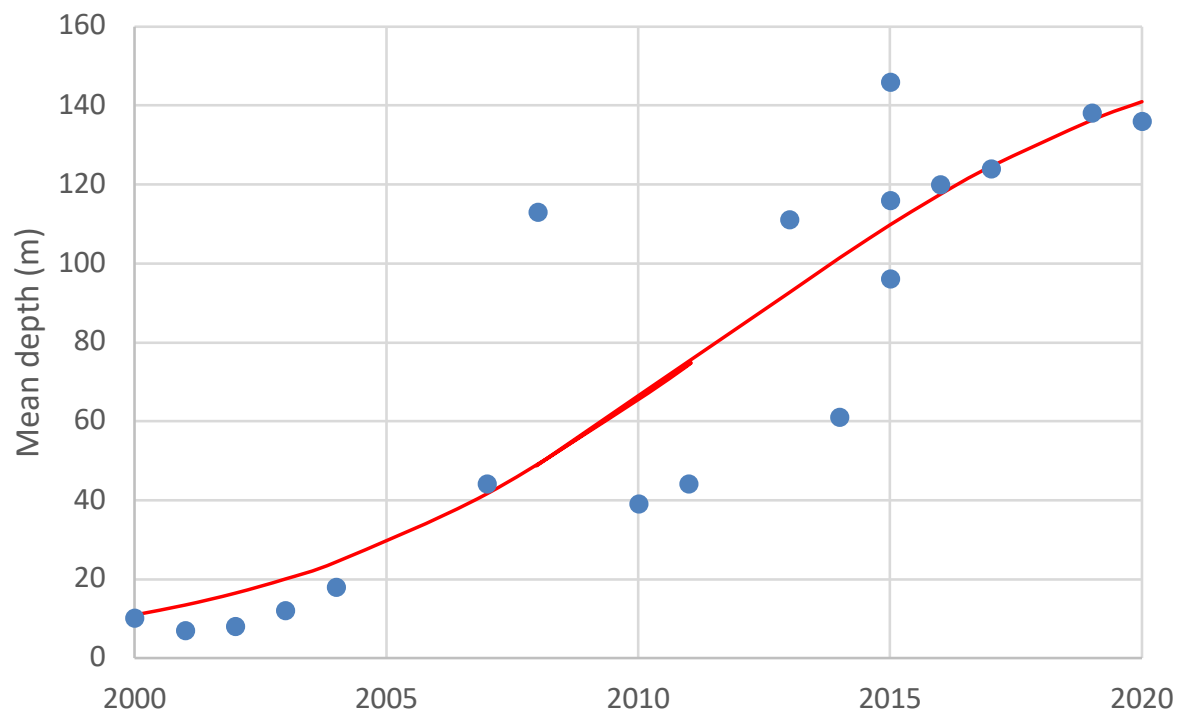

Source: European Commission [11]. 
Figure 7 - Average water depths and distance to shore of new offshore wind farms from 2015 to 2017

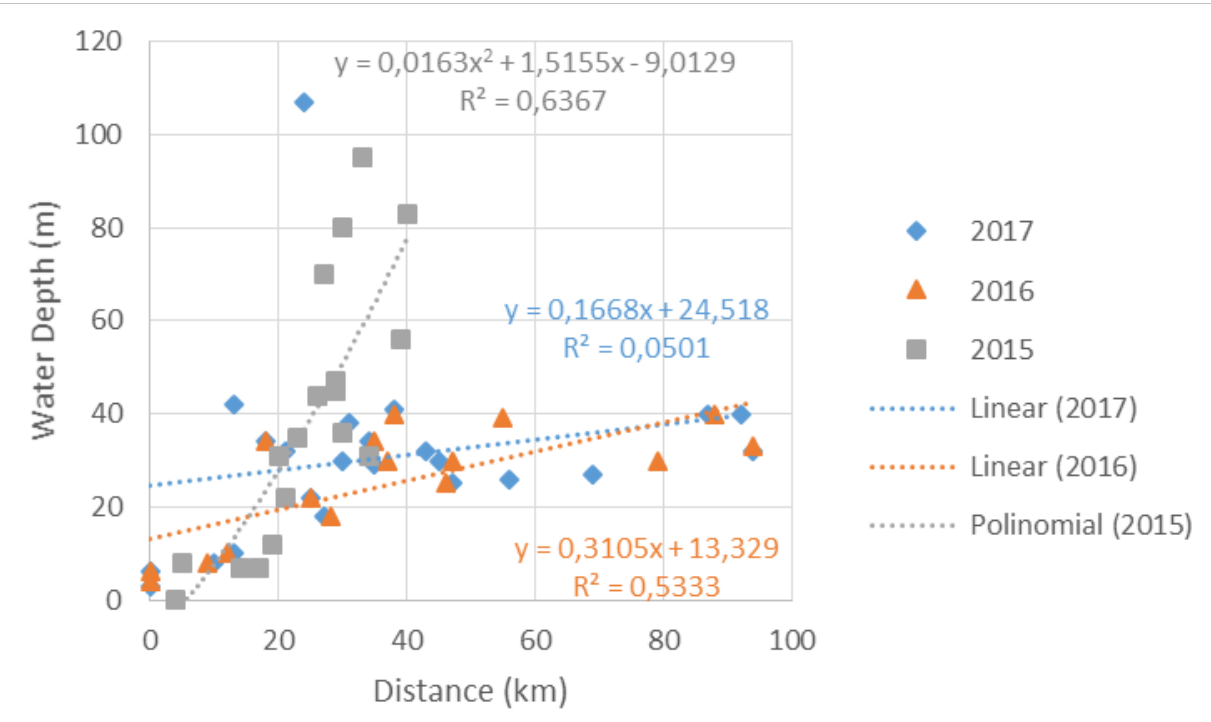

Source: EWEA [79]; WindEurope [75,80].

The structure and foundations of offshore wind power plants are different from those of land-based wind energy generators. Table 3 presents the main technical options for turbine foundations across various water depths, with a particular emphasis on the floating concepts that were adapted from the oil and gas industry (showing the complementarities or "couplings" with existing sectors, cf. [47]). Shallow waters and depths below 30 meters often employ monopile designs, while tripod and jackets are more used in transitional depths (between 30 and 50 meters). These designs can already be used in projects from shallow waters until relatively far from shore. Semi-submersible and floating designs could have a greater potential for energy cost savings by unlocking wind potential in deepwaters. Three designs are particularly disseminated: tension-leg platform (TLP); semisubmersible tri-floater; and spar buoy. Although inspired from the oil \& gas offshore know-how, floating designs need further adaptation to turbines and testing. They promise to reduce project costs through full assembly onshore, easier transportation and less complex installation, as well as to have a lower environmental impact on the seabed. However, costs are still high and should be reduced to become competitive against the fixed-bed structures $[54,68]$. 
Table 3 - Main options for offshore wind foundations according to water depth and turbine capacity

\begin{tabular}{|c|c|c|c|c|}
\hline Type & Description & $\begin{array}{l}\text { Depth } \\
\text { (meters) }\end{array}$ & $\begin{array}{l}\text { Capacity } \\
\text { (MW) }\end{array}$ & $\begin{array}{l}\text { Cumulative } \\
\text { installed share in } \\
\text { '17 (units [\%]) }\end{array}$ \\
\hline Monopile & $\begin{array}{l}\text { Most common foundation } \\
\text { consisting of a cylindrical steel } \\
\text { tube supporting the tower and } \\
\text { fixed into the seabed }\end{array}$ & $0-30$ & $1-2$ & 3720 [81.7\%] \\
\hline Jacket/Tripod & $\begin{array}{l}\text { (Jacket) corner piles } \\
\text { interconnected with bracings and } \\
\text { fixed into the soil; (tripod) three } \\
\text { diagonal braces anchored to the } \\
\text { seabed with piles }\end{array}$ & $25-50$ & $2-5$ & $447[9,8 \%]$ \\
\hline $\begin{array}{l}\text { Tension-leg platform } \\
\text { /Semi-submersible (floating) }\end{array}$ & $\begin{array}{l}\text { (TLP) tendons anchor the floating } \\
\text { structure on sea bottom; (Semi- } \\
\text { sub) floating barge anchored into } \\
\text { the seabed }\end{array}$ & $50-120$ & $5-10$ & $1[<0.1 \%]$ \\
\hline $\begin{array}{l}\text { Spar } \\
\text { (floating) }\end{array}$ & $\begin{array}{l}\text { Ballasted vertical tube to float } \\
\text { upright }\end{array}$ & $>120$ & $5-10$ & 6 [0.1\%] \\
\hline
\end{tabular}

Source: EWEA [68], WindEurope [80].

Figure 8-The most cited barriers to the development of floating offshore wind technologies according to the documents under analysis

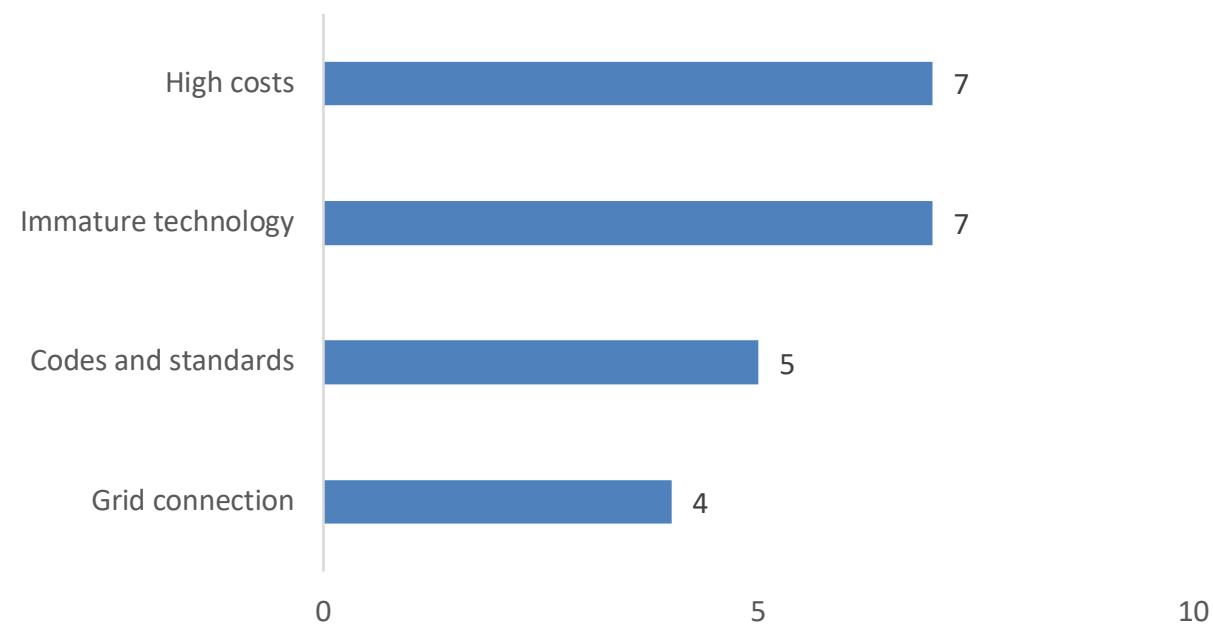

Number of documents citing the barrier

The analysis of the national roadmaps reveals a number of perceived obstacles to the development of floating offshore wind energy (Figure 8). The most frequently mentioned barriers are: high costs (explicitly referred in 7 out of 10 roadmaps); immature technology (7); and the need of codes and standards (5).

Investment costs are still high, which raises the output costs and constrains the market outlook for floating offshore wind [81]. Pilot projects received slightly over $300 € / \mathrm{MWh}$ in the United Kingdom through renewable obligation certificates or ROCs. More recently, the Japanese government also approved a feed-in tariff of 36,000 JPY (approx. $264 € / \mathrm{MWh}$ ) to support the deployment of floating offshore wind energy. This compares with an average levelized cost of energy (LCOE) from offshore wind energy (fixed foundations) of 180-200 €/MWh, between 2010 and 2017 [74,82-83]. However, 
recent auctions in Europe were gained with a price as low as $\$ 50 / \mathrm{MWh}$ for new additions in fixed offshore wind scheduled to start operating in the early 2020s [74].

Technology is immature and costs are expected to decrease as an effect of learning from the deployment of the first floating turbines. In fact, the learning rate was $20 \%$ for offshore wind (grounded) in the past decade, thanks to the installation of larger turbines and higher capacity farms [74]. Therefore further cost reduction remains crucial to ensure commercial viability of offshore wind using floating foundations.

Standardization is another challenge that needs to be addressed before market takes off. This typically requires investment in both R\&D and demonstration [20].

\subsubsection{Commercialization plans}

Roadmaps frequently trigger more concrete announcements of experimental projects and demonstrations of small, pre-commercial series. The investment in demonstrators is often part of a longer term perspective to commercialize the new technology. Experimentation projects (current and planned) are intermediary steps taken to bring the technology to the market [20]. These projects enable a first assessment of how roadmaps are impacting on decisions in the short term.

Table 4 shows the projects currently active on deepwaters offshore wind energy worldwide. The type of projects is discriminated into pilot, prototype and pre-production, coinciding with different demonstrators that mark the transition from science to technology (S-T), technology to application (T-A) and application to market (A-M), respectively, following the framework proposed in Phaal et al. [20]. The technology is clearly going through the prototype stage to enter into the pre-production stage, which will be eventually followed by the serial production stage. However, the early plans were too optimistic, expecting the first floating offshore wind farms to be connected as early as 2017 in Europe and in the US.

At the same time, the maximum unit capacity of turbines is increasing with plans to install 7,8 and even $10 \mathrm{MW}$ after 2020. The installation of larger size turbines helps to increase the capacity of the wind farms at lower costs (alternatively the number of turbines would have to increase in order to install an equivalent capacity). Note that up-scaling unit capacity signaled the end of the formative phase and the transition to large markets, in the case of the onshore wind energy [8].

Assuming that all the projects remained within the timelines, the cumulative installed capacity would reach $305 \mathrm{MW}$ in 2018. These numbers compare with the forecast of a consultant (DNV GL) which expects a slower start for floating wind energy - $120 \mathrm{MW}$ in 2018 - but a higher capacity of $870 \mathrm{MW}$ by the end of the decade. ${ }^{2}$

\footnotetext{
${ }^{2}$ http://www.wind-infotech.com/NL/paper/ehydt.html (accessed 10/8/2015)
} 
Table 4 - Selected active projects in deepwater offshore wind worldwide

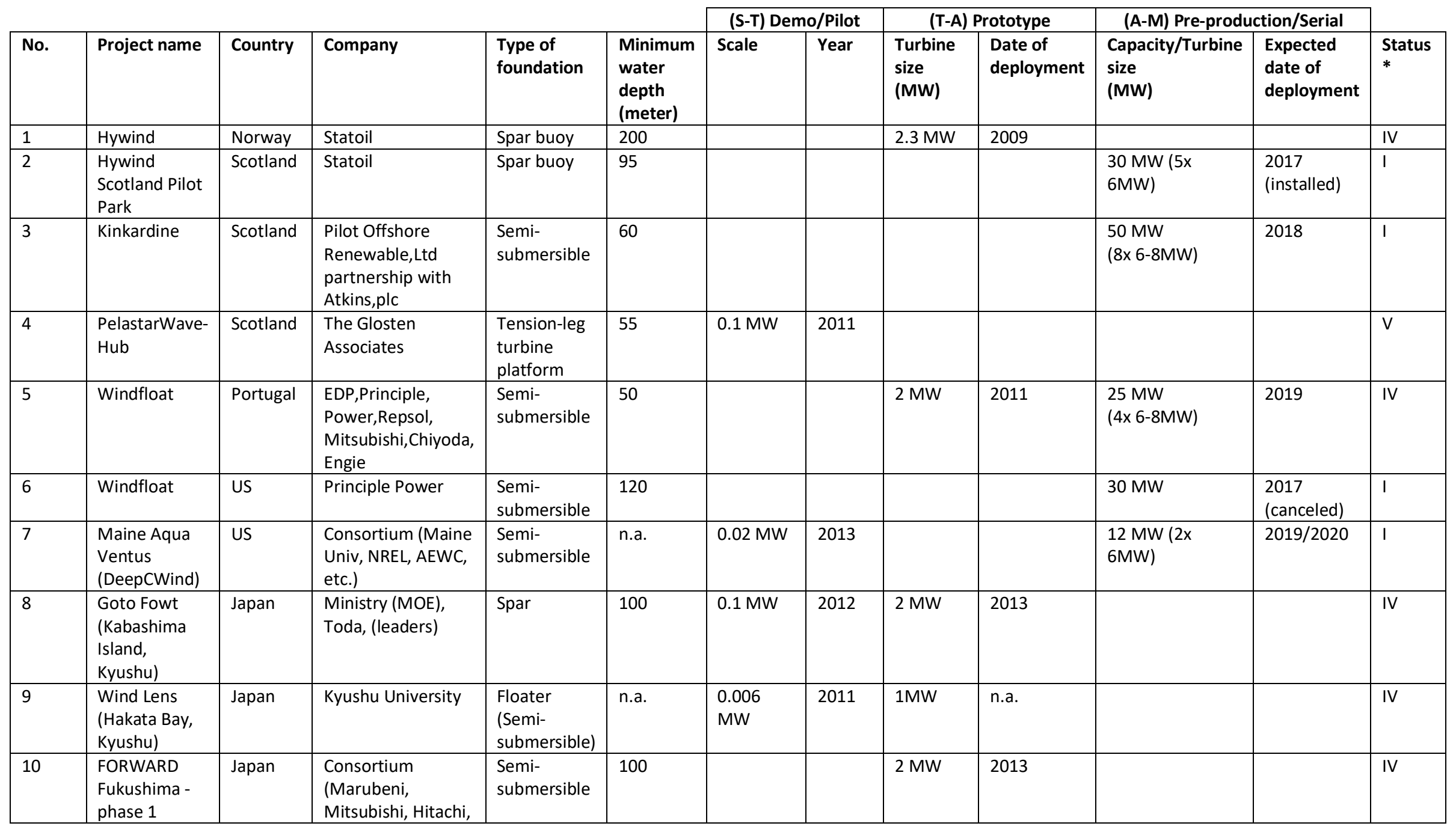




\begin{tabular}{|c|c|c|c|c|c|c|c|c|c|c|c|c|}
\hline & $\begin{array}{l}\text { FORWARD } \\
\text { Fukushima - }\end{array}$ & & $\begin{array}{l}\text { Tokyo University, } \\
\text { Japan Marine }\end{array}$ & $\begin{array}{l}\text { Semi- } \\
\text { submersible }\end{array}$ & 100 & & & $7 \mathrm{MW}$ & 2015 & & & III \\
\hline & Phase 2 & & $\begin{array}{l}\text { United, etc.) } \\
\text { supported by the } \\
\text { METI }\end{array}$ & Spar buoy & 100 & & & $5 \mathrm{MW}$ & 2015 & & & III \\
\hline 11 & Poseidon & Denmark & Floating Power & $\begin{array}{l}\text { Floater } \\
\text { (Semi- } \\
\text { submersible) }\end{array}$ & 45 & $0.03 \mathrm{MW}$ & 2009 & $5 \mathrm{MW}$ & n.a. & & & 1 \\
\hline 12 & Floatgen & France & $\begin{array}{l}\text { Gamesa, Acciona, } \\
\text { Ideol, etc. }\end{array}$ & Floater & 35 & & & $2 \mathrm{MW}$ & 2015 & & & II \\
\hline 13 & $\begin{array}{l}\text { Vertimed } \\
\text { (Inflow, } \\
\text { Vertiwind } \\
(1 \& 2))\end{array}$ & France & $\begin{array}{l}\text { Nenuphar, EDF EN, } \\
\text { (Technip) }\end{array}$ & $\begin{array}{l}\text { Semi- } \\
\text { submersible }\end{array}$ & 50 & $\begin{array}{l}0.035 \\
\mathrm{MW}\end{array}$ & 2009 & $2.6 \mathrm{MW}$ & 2015 & $\begin{array}{l}26 \mathrm{MW} \\
(13 \times 2 \mathrm{MW})\end{array}$ & $\begin{array}{l}2018 \\
\text { (canceled) }\end{array}$ & II \\
\hline 14 & $\begin{array}{l}\text { GICON-SOF } \\
\text { Pilot }\end{array}$ & Germany & Gicon GmbH & $\begin{array}{l}\text { Tension-leg } \\
\text { platform }\end{array}$ & 18 & & & $2.3 \mathrm{MW}$ & $\begin{array}{l}2018 \\
\text { (delayed) }\end{array}$ & & & 1 \\
\hline 15 & Nautilus & Spain & $\begin{array}{l}\text { Nautilus Floating } \\
\text { Solutions SL }\end{array}$ & $\begin{array}{l}\text { Semi- } \\
\text { submersible }\end{array}$ & n.a. & & & $10 \mathrm{MW}$ & 2021 & & & 1 \\
\hline 16 & $\begin{array}{l}\text { Sea Reed - } \\
\text { Groix }\end{array}$ & France & DCNS, Alstom & $\begin{array}{l}\text { Tension-leg } \\
\text { buoy }\end{array}$ & n.a. & & & & & $\begin{array}{l}24 \mathrm{MW} \\
(4 \times 6 \mathrm{MW})\end{array}$ & 2020 & II \\
\hline 17 & Balea & Spain & EVE & $\begin{array}{l}\text { Tension leg } \\
\text { platform or } \\
\text { Semi- } \\
\text { submersible } \\
\end{array}$ & 20 & & & & & $\begin{array}{l}26 \mathrm{MW} \\
(2 \times 5 \mathrm{MW}+ \\
2 \times 8 \mathrm{MW})\end{array}$ & 2020 & 1 \\
\hline 18 & FloCan5 & Spain & $\begin{array}{l}\text { Cobra, Gobierno de } \\
\text { Canarias }\end{array}$ & $\begin{array}{l}\text { Semi- } \\
\text { submersible }\end{array}$ & 50 & & & & & $\begin{array}{l}25 \mathrm{MW} \\
(5 \times 5 \mathrm{MW})\end{array}$ & 2020 & 1 \\
\hline
\end{tabular}

Status: I - Early planning; II - (Consent) Authorised; III - Under construction; IV - (Fully) Commissioned; V - Decomissioned.

Source: 4COffshore [84]; EWEA [68]; Main(e) [85]. 
To assess the speed and extent of the planed deployment of floating wind energy, we compare the growth of offshore wind in shallow waters with that in the near-shore using fixed structures. Fixed-bottom wind turbines are the closest technology that is comparable to floating wind turbines. We use data on both historical and forecasted growth, i.e., the time taken to move from several MW to dozens MW, hundreds MW, and thousands MW (gigawatt) wind farms. Figure 9 shows the results.

Figure 9 - Comparison of the growth of offshore wind farms with fixed-bottom (historically) and floating foundations (projected, as described in the demonstration plans)

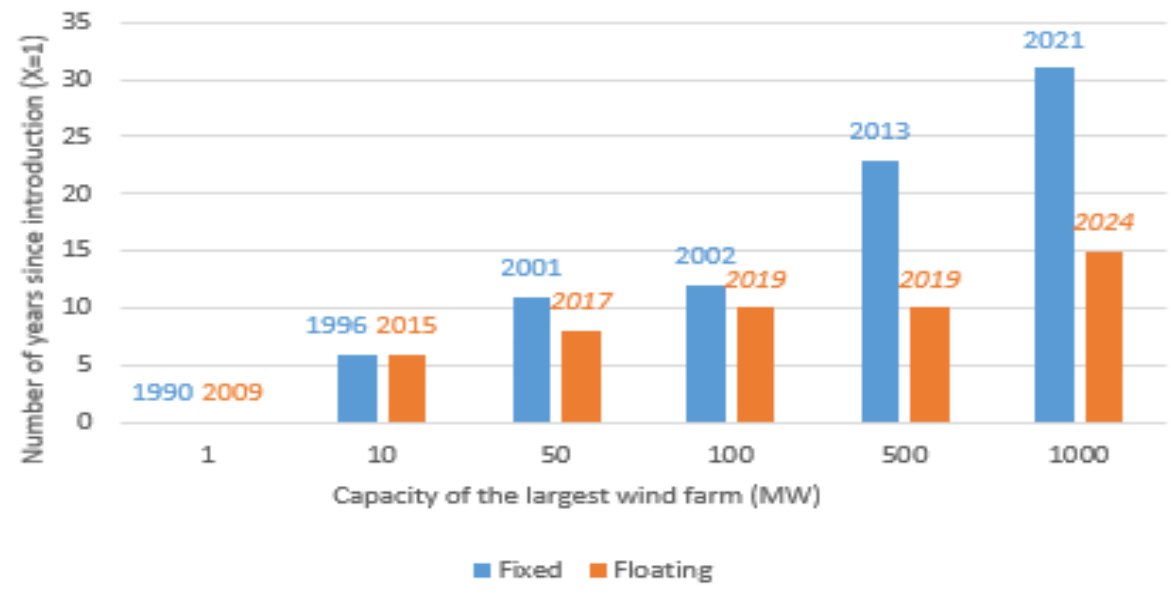

Author's elaboration using data from 4COffshore [84]; EWEA [68]; Main(e) [85]; Rodrigues et al. [54].

The two technologies (fixed and floating) take identical number of years (ca. 6 year) to pass from the construction of the first full-scale prototype (1990 and 2009 for bottom-fixed and floating offshore wind, respectively), to the first dozen MW farm (1996 and 2015 for fixed and floating structures, respectively). However, according to the plans, the transition to half hundred MW farms should be faster for floating wind, i.e. 8 years instead of the 11 taken in the case of fixed-ground farms. The rhythm accelerates for higher wind parks sizes up to the first gigawatt project, for which floating is expected to take 15 years, i.e. half the time expected for bottom-fixed farms (ca. 30 years). This result seems optimistic and suggests that actors anticipate that floating offshore wind energy may benefit from spillovers (e.g. knowledge, supply chain) from the previous deployment in the near-shore.

Figure 10 shows the evolution of wind turbine sizes for the largest models in several applications: onshore, offshore fixed and offshore floating. Up-scaling is stabilizing for onshore wind turbines, whereas rapidly growing for offshore (fixed) turbines, which are becoming larger than the ones onshore. Floating turbines are rapidly catching up with the other two types, further indicating its rapid scaling. Therefore, as pointed by Fowind [69], coordination is important between actors and public authorities to avoid unrealistic timelines that can deter developers from mobilizing the available resources for the development of the system. 
Figure 10 - Maximum unit size of wind turbines for application onshore, offshore fixed and offshore floating

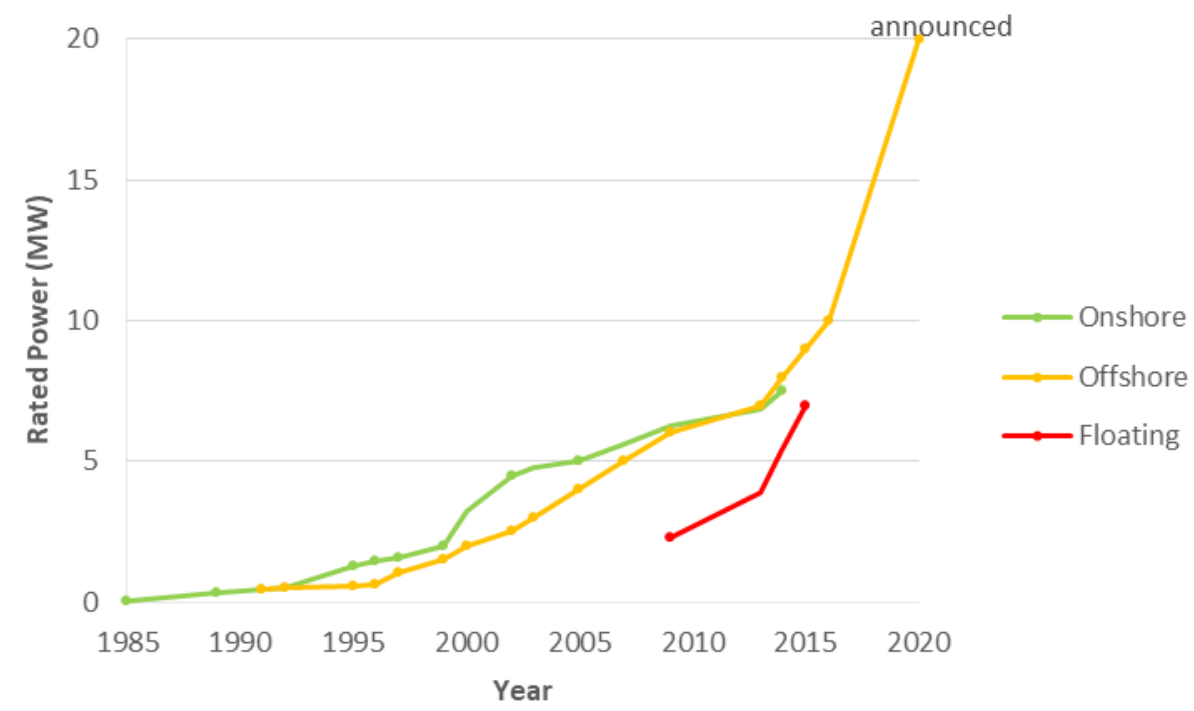

Author's elaboration using data from 4COffshore [8]; IRENA [86]; Rodrigues et al. [54].

\subsection{Structural components}

\subsubsection{Actors}

Roadmaps provide an overview of the actors that are already in the system, both as part of the diagnostics and through the reported actor participation. They can also inform about the perceived need to expand the number of actors and diversify activities and competencies.

The analysis of the proposed actions permits to identify the new types of actors (e.g. large energy firms, capital providers, community leaders) and the complementary areas that need to be involved. Several roadmaps mention the competencies required to develop the value chain, in particular related to operating offshore, such as the ones present in the marine or the oil \& gas industries. In fact, profiting from synergies with oil \& gas competencies and infrastructure can reduce costs and solve transmission issues [74]. They equally identify the new types of activities that have to be performed by the actors already present in the system and the resources that may be required for that purpose, e.g.: from development to demonstration; from prototype building to larger scale manufacturing; from research to market development.

Some activities are considered critical and the actors providing them singled out as requiring particular attention. These activities include provision of financing by different type of actors (from government to private investors), at different levels (from R\&D to demonstration and to commercialization), training of human resources, setting- up early infrastructures for demonstration and test.

The roadmaps analysis uncovers key players and the nature of functions they are expected to perform for the development of the system. While research organizations remain important, industrial actors assume an increasingly relevant role as the innovation matures and approaches commercialization. In fact, the roadmaps explicitly stress the need to mobilize 
industrial actors with competences that go beyond the "core" energy technology, focusing on expertise on the logistics of offshore operation or on advanced manufacturing. Policy actors are viewed as particularly critical at this stage of development. When the roadmaps are of government initiative, their involvement is automatically assumed. But when they are of the initiative of other system actors such as collective organizations, like in Portugal and Japan, it is necessary to assess whether policy actors participated in their formulation and whether and how they are expected to endorse them subsequently.

Roadmaps also elucidate about the motivations of the actors (private as well as public) in the development of the system. They often set the achievement of an early positioning in the emerging system as a country goal, with a view to gaining competitive advantages. This includes the need to develop a national industry across the value chain - or at least in some of its components - which requires the mobilization of national actors and existing competences in related sectors (sometimes redirecting or upgrading them). Although roadmaps generally recognize that offshore wind energy is an international field, the competition from actors from other countries is taken into account in only a few cases (not least to call for a stronger public support for the domestic technology).

\subsubsection{Networks}

Roadmaps provide indications on the type of interactions that are deemed to be necessary for the development of the system. The identification of the actors currently in the system permits to gain insights into the emerging networks.

At this level several roadmaps detail the value chain that needs to be built and the nature of the upstream and downstream relations that have to be established with complementary sectors (a variety of activities related to operating at sea, materials industry, robotics and control systems, to name a few). This often includes the networks that have to be reinforced among the actors already in the system, and between these and newcomers.

Several roadmaps provide indications towards wider, more formal, networks that favour actors' alignment and coordination. This includes the setting up of large demonstration projects, along with the creation of shared infrastructures that accelerate learning processes and the creation of interdependencies. They also call for the formation or reinforcement of collective organizations that provide an arena for identifying shared interests and for acting on their behalf. In this context, some roadmaps also point to the need to develop international collaborations (e.g. knowledge networks, standardization groups).

The analysis thus permits to uncover the new types of networks that are expected to emerge in the process of structuration for system up-scaling. Examples include: research and technology, business, intermediation, policy lobbying, as well as larger networks that encompass a variety of actors and activities and have a system coordination role like the Offshore Wind Industrial Council (OWIC) in the UK, the Offshore Wind Innovation and Demonstration Initiative (OSWindD) in the US, or the WAVEC Offshore Renewables in Portugal.

Overall, the roadmaps anticipate an expansion in the number and variety of actors and an intensification of the relationships between them, often proposing actions and/or policy measures that foster such developments. They emphasize the need for diversification of the activities and competences to achieve a faster and more sustained development of the 
innovation system associated with the technology, and in some cases point to the necessity of greater coordination.

\subsubsection{Institutions}

The creation of institutions is recognized as a crucial part in the preparation for large scale commercialization and roadmaps present details about the institutional needs. The literature review shows that alignment with existing structures increases legitimacy, and the creation of technology-specific institutions like standards marks the progress of the system in early years (see, e.g., [6]).

Roadmaps provide indications on the relevant regulatory aspects that constrain the system development and suggestions to address them. There is a broad recognition of the need to establish technology-specific regulation ex ante to accelerate growth. For that reason, they often propose the introduction of regulation at several levels, including: regulation of sea activities (e.g. marine spatial planning); permitting and licensing; grid connection, and codes and standards.

Roadmaps make technology specific policy proposals, whose acceptance and implementation depends on the initiative of their formulation. When roadmaps are of government initiative, they are an element of the policy for the field and are likely to depict policy proposals already accepted by the government (legitimation). When roadmaps are of actor initiative, they tend to stress the need to gain the adhesion of policy makers to their vision and proposals, bringing about favourable policies. This is often accompanied by optimistic views about the potential of the technology to deliver a high amount of energy at affordable costs (e.g. $4 \mathrm{GW}$ of floating wind energy in Japan by 2030 expected by the local wind association). They also tend to present a national focus, namely highlighting the importance of stimulating the internal market for the development of an export industry (see also [87]).

The roadmaps emphasize the need to create a positive view of the technology in the community. They stress the advantages relatively to onshore wind in terms of environmental gains and avoidance of negative reactions against the installations. The roadmaps often call the attention of local communities to the economic advantages derived from the new activities (e.g. new investments in the value-chain, job opportunities). But several roadmaps point to the need to prevent conflict with the other activities that share the ocean space (like the powerful fishery industry in Japan). In these terms, roadmaps also act as instruments to raise public awareness and approval and, thus, increase legitimation.

\subsection{Functions}

This section aims to understand whether and how the roadmaps contribute to accelerate the transition to growth, through the performance of the system functions which they are expected to more directly affect: direction of search and legitimation. Such core processes are indicators of, respectively, the social recognition of the technology and the attractiveness of 
the system to investments from other sectors [30]. The performance of legitimation and guidance can spur other system functions and, in this way, the dynamics of growth $[27,38]$.

In particular, the analysis examines whether and how roadmaps perform the aforementioned functions and contribute to fulfill the other key innovation processes, such as resource mobilization and market formation, which are necessary for growth.

\subsubsection{Influence in the direction of search}

Influence in the direction of search refers to the capacity to articulate expectations and provide guidance to emerging technological innovation systems, namely by raising the visibility of a technology or setting goals and timeframes for both technological and market development [21].

The roadmaps under analysis define and convey a vision of the future. They all contribute to improve, to a greater or lesser extent, the visibility of offshore wind. Roadmaps set guidelines for action which are more or less detailed depending on the cases. Greater detail is found in:

- more focused roadmaps that address specifically offshore wind in deepwaters instead of the broader class of marine renewable energy technologies;

- roadmaps originating from countries with greater previous involvement with the technology (e.g. the UK) or that strongly invest in knowledge development (e.g. the US)

- roadmaps that are not one-off but rather follow-up from earlier documents, such as in the UK or Portugal, which end-up being more substantiated and detailed.

Thus the analysis suggests that roadmaps adjust to the stage of development of the system at country level.

Concerning the operationalization of the vision, all countries define goals for technology development and six of them additionally set-up intermediate steps. The only exception is Norway, whose "Offshore Energy Act" refers to targets to be set later. The plans of deployment range from $27 \mathrm{MW}$ in Portugal to $100 \mathrm{MW}$ in Japan by 2020, and up to 4,000 MW in Japan by 2030. Intermediate steps often refer to deployment, but there are cases where it relates to a technological target such as costs reduction (e.g. GBP 100/MWh in UK or $\$ 0.10 / \mathrm{kWh}$ in the US) by 2020.

The competition from other technologies appears in few roadmaps and is often associated with the acknowledgement of the high costs of floating offshore wind. This is more frequent in the cases of countries that already have a high share of renewables, or when the document refers to more immature technologies (e.g. ocean energies) in order to make the case for the investment in offshore wind.

The roadmaps often emphasize the domestic production of a substantial number of components. They present these components as complementary activities that can provide opportunities for organizations from a variety of fields (including declining sectors like metalworking) to broaden their markets and to increase their export prospects. All documents have a strong national flavor, frequently pointing to the interest of developing competitive capacities and eventually achieving first-mover advantages. They defend the need to develop or reinforce the value chain at country level, namely by profiting from existing strengths in 
complementary areas that are critical for the development of an "industry" around offshore wind.

The national focus appears nevertheless to be excessive considering the highly internationalized nature of the field, leading to some neglect of the potential competition from other countries with similar goals (the UK roadmap is a rare exception). In the limit, foreign organizations are never referred to like in the Japanese roadmap. This can be a side effect of roadmaps in the effort to mobilize national actors, which is explored in more detail later.

Therefore, the roadmaps and equivalent documents influence the direction of search in some way or another. At least, they contribute to shape and disseminate the expectations about offshore wind in deepwaters. But the effectiveness of the guidance will depend on whether they have the capacity to attract actors from other sectors and to stimulate the other innovation activities, something we look at in the following sections.

\subsubsection{Legitimation}

Legitimation refers to the socio-political process by which actors shape expectations around the technology [34]. As regard the roadmap analysis, the determinants of legitimation include the participatory character of the roadmapping process, and the capacity to spur the formation of technology-specific institutions such as codes and standards.

The level of participation can determine the capacity of roadmaps for creating persuasive expectations around the technology. As pointed out above, all documents define a vision and expectations (more or less detailed), which are seen as catalyzing action. But the extent to which the roadmaps contribute to create legitimacy is related with the quality of the process that led to the development of these visions and expectations, in particular how participatory and inclusive the process was [18].

Roadmaps do not always detail the process followed in their elaboration. But for those who do, we observe an attempt to achieve comprehensive diagnostics and projections and to resort to recognized experts in order to raise social recognition of the technology (e.g. FR13). Documents also differ in terms of the origin of initiative, breadth and level of actor participation. In what concerns participation, it differs in extent and nature, which may influence future acceptance and engagement on the guidelines set. There is usually an attempt to involve key actors - at least in terms of consultation - and achieve a wide diffusion (and sometimes debate) of the vision and proposals. Most documents stress the need of extending the number and range of participants in the system as a condition for its development, and several define strategies for that purpose. This includes the promotion of specific initiatives, networks or infrastructures (e.g. setting-up demonstration sites, solving grid connection problems), often supported by financial incentives that signal preferable development paths and enable the alignment of actors along them.

Most roadmaps are of government initiative, but in two countries they are of actor initiative (Japan (JA14) and Portugal (PO14R, P014P)). The origin of the initiative - private actors vs. public actors - has an effect in its capacity to provide legitimation (and guidance). If a large participation of private actors is more likely to generate broader consensus, the involvement of the government tends to ensure greater policy impact. In particular, the roadmaps of actor initiative stress the need for government endorsement of the preconized visions and 
proposals. In that, they can be regarded as a documental piece of the lobbying activities to reinforce acceptance (legitimacy) and influence further development.

The creation of technology-specific institutions reinforces legitimacy and appears as a priority in the generality of roadmaps. Standards should be set before market take-off, as well as regulation at various levels, such as the interactions with other marine activities, to avoid social resistance. This recognition is sometimes complemented with specific recommendations, the most common being the urge for maritime spatial planning.

Public perception is an important issue in the surveyed documents. The roadmaps tend to present floating offshore wind as avoiding some of the acceptance problems associated with fixed systems installed closer to the coast (not to speak of those inland), and thus less prone to resistance. They sometimes point to survey results to support these assertions (e.g. UK13S). There is almost always the preoccupation of anticipating and addressing eventual conflicts with activities and communities that share the ocean space, in what is a clear attempt to improve the public opinion on the technology.

Overall, these documents endeavor to set directions for action and provide instruments that aim at encouraging actors to engage in activities along them - even if with different levels of specificity. The government origin of most of the roadmaps ensures its support to the directions set (at least until the end of their mandate). However, the diversity in terms of actor involvement (type, level and nature), and the challenges this may raise to a consensus around the shared goals, suggests that roadmaps may vary in what concerns the legitimacy they provide. There is nevertheless an attempt to promote public acceptance and some preoccupation with the engagement of key actors (both existing and new).

\subsubsection{Impact on the other functions}

Roadmaps can impact the execution of several key innovative activities (e.g. knowledge creation, infrastructure building, investment in manufacturing plants) that are needed for transition. To understand the extent to which they influence the other system functions, we searched in the roadmaps for the elements that acknowledge and address the barriers to the development of floating offshore innovations previously identified in the literature.

Former research identifies several barriers to the growth of offshore wind energy (both in the near-shore and in deepwaters), including the lack of specialized human resources, grid connection and financial capital $[13,50]$. These barriers relate to the underperformance of several system functions (the so-called "weak functions" cf. Bergek et al. [26]), including resource mobilization and market formation.

Table 5 shows the policy challenges related to the performance of these weak functions in the European countries that develop offshore wind energy in shallow waters (particularly in the United Kingdom and Denmark) and compares with those in a country that is among the pioneers in the development of floating offshore wind (Portugal). 
Table 5 - Comparing policy issues associated to the two weak functions blocking the development of offshore wind energy innovation systems in Europe (particularly UK and Denmark) and in a pioneer country in floating offshore wind (Portugal)

\begin{tabular}{lll}
\hline & EU (including UK and Denmark) * & \multicolumn{1}{c}{ Portugal } \\
\hline Market formation & - Alignment of member states & - Slow increase in final electricity consumption \\
& market opportunities & - Support to internationalization of activities \\
& & - Better grid interconnections with other \\
& & European countries (for RES electricity \\
export)
\end{tabular}

* cf. Wieczorek et al [12-13] and Jacobsson and Karltorp [50].

Policy challenges in italic are more specific to Portugal and result from author's analysis, namely to the surveyed documents (PO14R, PO14P).

To accelerate growth, more specialized skills are necessary along with the availability of financial capital and of early infrastructures for offshore wind energy. The analysis of Table 5 reveals the importance given to the internationalization of the industry in both EU and Portugal, as well as to the spillovers from the development of other maritime activities and to the complementarities with the existing renewable energy sectors (in the case of Portugal). These policy challenges depend on the motivation and formation of expectations around floating offshore wind, which interact with the legitimation process. The table suggests that stable regulation (legitimation) can directly help with the mobilization of human and financial resources and indirectly contribute to market formation. For example, several roadmaps alert for the importance for industry take-off of training human resources (that needs solid prospects of market growth) since it could help to provide the required competencies in a timely way. Similarly, by advocating a pathway of growth for installation and production, roadmaps can help planning the establishment of early grid connections. 
Table 6 - Support mechanisms and grid connection regimes for offshore wind energy in selected countries. Source: Higgins and Foley [88]; Veum et al. [89]; FOWIND [69]; Mizuno [90]; www.res-legal.eu

\begin{tabular}{|c|c|c|c|c|}
\hline Country & $\begin{array}{l}\text { Main support } \\
\text { mechanism }\end{array}$ & Support level (€/MWh) & Additional incentives & $\begin{array}{l}\text { Responsibility } \\
\text { for grid } \\
\text { connection }\end{array}$ \\
\hline \multicolumn{5}{|c|}{ European countries } \\
\hline Denmark & $\begin{array}{l}\text { Tender + feed-in } \\
\text { premium }\end{array}$ & $\begin{array}{l}0.372 \mathrm{DKK} / \mathrm{kWh} \text { (approx. } 5 € / \mathrm{MWh} \text { ) for } \\
\text { first } 30 \mathrm{TWh} \text { limited to } 20 \text { years (result } \\
\text { of the tendering process for Kriegers } \\
\text { Flak in 2016) }\end{array}$ & $\begin{array}{l}\text { Capital grants for R\&D, } \\
\text { co-funding for R\&D and } \\
\text { demonstration projects } \\
\text { through tender process } \\
\end{array}$ & TSO \\
\hline France & $\begin{array}{l}\text { Tender }+ \text { feed-in } \\
\text { tariff (under } \\
\text { renegotiation) }\end{array}$ & $\begin{array}{l}170-200 € / \mathrm{MWh} \\
\text { (result of the first tendering round) }\end{array}$ & $\begin{array}{l}\text { Capital grants (e.g. "grand } \\
\text { emprunt") }\end{array}$ & Developer \\
\hline Germany & $\begin{array}{l}\text { Feed-in tariff or } \\
\text { feed-in premium }\end{array}$ & $\begin{array}{l}39-154 € / M W h \text { according to the } \\
\text { duration for a maximum of } 20 \text { years }\end{array}$ & $\begin{array}{l}\text { Soft loans public German } \\
\text { KfW bank for first } 10 \text { parks } \\
\text { Training programs for } \\
\text { installers } \\
\text { Capital grants for RD\&D }\end{array}$ & TSO \\
\hline Netherlands & $\begin{array}{l}\text { Tender + sliding } \\
\text { feed-in premium }\end{array}$ & $\begin{array}{l}\text { Difference between bided price and } 2 / 3 \\
\text { of the long term average electricity } \\
\text { price (up to a predetermined strike price } \\
\text { corrected with factors for depth and } \\
\text { distance to shore) over } 15 \text { years }\end{array}$ & $\begin{array}{l}\text { Soft loans and tax incentives } \\
\text { Support to training } \\
\text { programs } \\
\text { Capital grants for R\&D }\end{array}$ & $\begin{array}{l}\text { Developer } \\
\text { (under debate) }\end{array}$ \\
\hline Norway & Capital grants & $\begin{array}{l}\text { Currently no support incentives for } \\
\text { development of offshore wind parks. } \\
\text { Joint Norwegian-Swedish certificate } \\
\text { trading scheme introduced January } \\
\text { 2012. However, the certificate price is } \\
\text { too low (falling below } 20 € / M W h \text { in the } \\
\text { middle 2016) to be attractive for } \\
\text { offshore wind energy (OWE) developers. } \\
\text { Additional support for OWE not yet } \\
\text { identified. }\end{array}$ & $\begin{array}{l}\text { Capital grants for } \\
\text { demonstration projects }\end{array}$ & Developer \\
\hline Portugal & Feed-in-tariff & $\begin{array}{l}168 € / M W h \text { (Portaria n. } 0202 / 2015 \text {, } \\
\text { Portaria n. } .286 / 2011 \text { ) } \\
\text { (demonstration and pre-commercial } \\
\text { phase) }\end{array}$ & $\begin{array}{l}\text { Capital grants (e.g. EU } \\
\text { NER300, FAI) } \\
\text { Soft loans (e.g. from EIB) }\end{array}$ & $\begin{array}{l}\text { TSO } \\
\text { (derogation for } \\
\text { project } \\
\text { Windfloat) }\end{array}$ \\
\hline Spain & $\begin{array}{l}\text { Either a feed-in } \\
\text { tariff or feed-in } \\
\text { premium } \\
\text { (suspended since } \\
\text { 2012) }\end{array}$ & Currently suspended & $\begin{array}{l}\text { Support for training and } \\
\text { education }\end{array}$ & Developer \\
\hline UK & $\begin{array}{l}\text { Feed-in premium } \\
\text { (contracts for } \\
\text { difference) } \\
\text { replaced } \\
\text { quota obligation } \\
\text { (ROC) } \\
\text { in March } 2017 \\
\end{array}$ & $\begin{array}{l}\text { 1.5 Renewable Obligation Certificates } \\
\text { (ROCs) per MWh over } 20 \text { years } \\
\text { (2 ROCs typically in Scotland, raising to } \\
\text { 3.5 ROCs for floating offshore wind } \\
\text { demonstrator projects in Kincardine) } \\
\text { average ROC price } £ 42.73 \\
\text { (approx. } 56 € \text { ) (June } 2014 \text { ) }\end{array}$ & $\begin{array}{l}\text { Climate change levy } \\
\text { Capital grants }\end{array}$ & Developer \\
\hline \multicolumn{5}{|c|}{ Non-European countries } \\
\hline Japan & Feed-in tariff & 36.000 JPY (approx. 264€) per MWh & $\begin{array}{l}\text { NEDO grants for research } \\
\text { and demonstration }\end{array}$ & Developer \\
\hline US & no/n.a. & $\begin{array}{l}\text { Power purchase agreement subject to } \\
\text { approval of each state Public Utilities } \\
\text { Commission }\end{array}$ & $\begin{array}{l}\text { DOE grants for RD\&D and } \\
\text { deployment }\end{array}$ & Developer \\
\hline
\end{tabular}

TSO - transmission system owner; RD\&D - research \& development and demonstration; n.a. - not available.

a http://www.capewind.org/when/timeline 
Table 6 reviews the incentive schemes that have been deployed to support the emergence of offshore wind energy, including in deepwaters. The most active countries in deepwaters - UK, Portugal and Japan - have set clear targets and timelines for deployment (more details in the separate report Bento \& Fontes, 2017). They have approved feed-in tariffs (with and without tenders) above $150 € / M W h$ and attributed capital grants for R\&D and demonstration, including of full scale systems to prove the viability of concepts. Yet developers must pay for the grid connection in the majority of countries, with some exceptions like Denmark and Portugal. The emphasis on these support schemes reveals an effective "guidance" towards an accelerated commercialization, as well as some level of institutionalization (legitimacy) of the activities to undergo at this level.

In summary, the setting-up of official targets and timelines typically accompanies the enactment of incentive mechanisms that are intended to support the formation of the early markets. Through their effect in the guidance and legitimacy, roadmaps appear to have a de facto impact on market formation. However, and despite the supportive measures, a lack of key conditions, such as specialized skills, financial capital and infrastructures, continue to delay investments in larger projects. More research is still needed to understand the capacity of roadmaps to affect the performance of the other key functions for system up-scaling, namely resource mobilization and materialization, whose fulfillment could be assessed, in the future, with more data on investments, jobs creation and energy production.

\section{Discussion and conclusion}

The paper aims to understand the challenges faced to up-scale innovations and accelerate their growth, through the analysis of an emerging energy technology (floating offshore wind) which claims a high potential for generating large quantities of low carbon electricity. This is a multidimensional phenomenon that transcends the technological aspect and, for that reason, a systemic approach is taken. In particular, the paper focuses on the process of creation and sharing of collective strategies, through the study of roadmaps.

The contribution of this study for the literature is twofold. First, it improves the conceptualization of the dynamics of change in technological innovation systems, adding to the recent efforts in this area (see $[6,78])$. Second, it operationalizes system building processes through the review of the socio-technical processes involved in the up-scaling of floating offshore wind.

A more detailed analysis of the roadmaps reveals the way floating offshore wind is preparing for market take-off, from the viewpoint of the actors and networks. It uncovers great similarities in the way the roadmaps foresee the system's transformation. Similarities can namely be found in what concerns:

- expectations regarding the acceleration of innovation (more "linear" visions of the succession of pilot stage, pre-commercialization stage and commercialization stage);

- main barriers and obstacles to address;

- focus on technological requirements: demonstration of full-scale operating systems; cost reduction and standardization; development of an industrial value chain (even in countries where the innovation system is more immature);

- recognition of the need to expand networks (size and scope) and align actors in order to create the value chains; 
- priority areas of action, including the development of competencies and standardization;

- critical role of policies to achieve goals;

- focus on domestic development (frequently seeking prime-mover advantages).

These similarities denote a convergence of visions and of generic strategies to achieve them. They signal a shared perspective on the "structuration" of the innovation system, as part of the process of up-scaling and transition to the main markets. Interestingly, this convergence is also visible in the case of countries whose system is still in an embryonic stage, but whose visions and proposals take as reference the processes taking place in more advanced contexts (e.g. France in relation to Japan and the UK).

There are nevertheless some differences in the more specific goals and strategies, which can be related to different country conditions. These include the weight of renewable energies, the performance of offshore activities (e.g. offshore wind or oil \& gas), industrial specialization (e.g. level and type of activity in complementary sectors along the value chain), country resources that can be mobilized and sectoral organization. These findings provide further support to the claim that the strategies conveyed in roadmaps are determined by the technological and socio-economic context [39]. There are also differences concerning the origin of the initiative and actor inclusiveness which can affect their effectiveness, particularly in terms of the roadmaps' role as sources of legitimation.

To understand the challenges in preparing for up-scaling, key changes in the development of both the technology and the industry are compared. In accordance with the technological innovation systems literature, the emergence of a new sector can be analyzed as a systemic process that encompasses at least five components: technology, actors and networks, policy and institutions, functions (system performance) and context. Table 7 summarizes and compares the main features of the emergence of the floating offshore wind industry until now, and the plans for its up-scaling according to the roadmaps analyzed.

The phase of emergence is mainly about the progresses of the technology and the way it becomes more mature and competitive against the incumbent at the end of the formative phase. The entry of new firms is crucial for the formation of networks to support knowledge development and coalitions around the technology. Public organizations enact incentives and regulation to enable the first demonstrations. The existing offshore infrastructure (interconnections, ports, factories and so on) contributes to a more rapid progress towards upscaling.

The entry into the up-scaling phase, as envisioned by the plans, involves a series of rapid and more profound changes in multiple components. Standardization is needed to build the value chains and grasp economies of scale at both production and unit levels. At the same time the market should grow to reap the benefits of technology maturation. More actors need to enter with complementary skills and assets, namely from adjacent sectors (shipbuilding, maritime transport and so on), attracted by the perceived potential of the technology. For that, the plans call for the establishment of social, political and legal support that promotes private investments through reducing the uncertainty on both the technology and the market.

The comparison between the emergence and the up-scaling of floating wind energy (as conveyed by the roadmaps) reveals an evolution in the motors of innovation. While the 
emergence of the technology was led by entrepreneurial experimentation that triggered investments in R\&D and legitimation, the roadmaps envisage up-scaling primarily as driven by the influence in the direction of search and by lobby for more support to markets and infrastructures. This suggests, therefore, that guidance and legitimacy have a role in up-scaling that is even more important than predicted by the theory.

Table 7-Main features of the emergence period and of the plans for up-scaling the floating offshore wind industry

\begin{tabular}{|c|c|c|}
\hline Component & Emergence & Plans (up-scaling) \\
\hline \multirow[t]{2}{*}{ Technology } & $\begin{array}{l}\text { Emergence of three main types of } \\
\text { floaters (spar buoy, semi-submersible, } \\
\text { tension leg platform) }\end{array}$ & $\begin{array}{l}\text { Standardization and cost reduction in } \\
\text { floaters and installation }\end{array}$ \\
\hline & $\begin{array}{l}\text { Innovation in turbines with ever } \\
\text { increasing scales but production costs } \\
\text { remain an issue }\end{array}$ & $\begin{array}{l}\text { Interaction between a growing market } \\
\text { and technology maturation. } \\
\text { Development of complementary } \\
\text { technologies (transmission, grid } \\
\text { connection and so on) }\end{array}$ \\
\hline \multirow[t]{2}{*}{ Actors \& networks } & $\begin{array}{l}\text { Entry of players and formation of } \\
\text { supporting coalitions }\end{array}$ & $\begin{array}{l}\text { Attract newcomers to expand value } \\
\text { chains, business-oriented networks and } \\
\text { coalitions, coordinated by established } \\
\text { system builders }\end{array}$ \\
\hline & $\begin{array}{l}\text { Active involvement of incumbent } \\
\text { actors (utilities, manufacturers, oil \& } \\
\text { gas companies) }\end{array}$ & $\begin{array}{l}\text { Improve the social acceptability of the } \\
\text { technology }\end{array}$ \\
\hline Policies \& institutions & $\begin{array}{l}\text { Creation of the first incentives } \\
\text { (demonstration grants, feed-in tariffs } \\
\text { and so on) } \\
\text { Integrate a mature institutional } \\
\text { configuration with a slowly reforming } \\
\text { market structure }\end{array}$ & $\begin{array}{l}\text { Influence the government to lead the } \\
\text { development of the sector along with } \\
\text { the industry } \\
\text { Creation of technology-specific } \\
\text { institutions (codes, regulation, licenses } \\
\text { and so on) to help in the } \\
\text { implementation of the plans }\end{array}$ \\
\hline $\begin{array}{l}\text { System performance } \\
\text { (functions) }\end{array}$ & $\begin{array}{l}\text { Subsidized demonstrations revealed } \\
\text { potential (generation, capacity factor, } \\
\text { reliance) }\end{array}$ & $\begin{array}{l}\text { Transition to an increasing share of } \\
\text { private capital requires prospects of } \\
\text { economic viability. Materialization (test } \\
\text { facilities, factories, infrastructures and } \\
\text { so on) for higher scale production and } \\
\text { system integration is a vital question }\end{array}$ \\
\hline Context & $\begin{array}{l}\text { Interactions with other offshore } \\
\text { activities (oil \& gas, marine } \\
\text { engineering, ports and others) }\end{array}$ & $\begin{array}{l}\text { Explore synergies with adjacent sectors } \\
\text { for accessing resources while helping in } \\
\text { the recovery of declining traditional } \\
\text { activities (e.g. shipbuilding) }\end{array}$ \\
\hline
\end{tabular}

The analysis shows that roadmaps can be an instrument for the performance of both legitimation and guidance. The literature suggests that the performance of these two processes is important in system structuration, by triggering changes in the other functions, such as resource mobilization and market formation, that are important for technology upscaling [8,30,37-38]. In fact, roadmaps often set targets for diffusion, recommend policies or indicate areas for priority investments.

We found several deviations between the visions and orientations set out in the roadmaps and the historical evidence from fixed offshore wind. Roadmaps are overly optimistic when compared with the pace of growth of the offshore wind featuring fixed structures. The scenarios depict floating offshore wind up-scaling twice as fast as the historical rate of the 
"fixed" offshore wind. In addition, while the roadmaps address the processes that are identified in the literature as necessary for up-scaling floating-offshore wind, namely dealing with resource mobilization and market formation, the resulting actions do not appear to be effective enough to produce the expected results. Indeed, we identify a series of policies enacted around the publication of the roadmaps (e.g. financial incentives, interconnection grants) that have been unable, so far, to trigger the necessary investments. This lack of efficacy may stem from the inflated expectations, which are particularly evident in roadmaps from the initiative of stakeholders, who overstate promises in order to persuade the policy-makers. External shocks [91] (e.g. economic crisis, changes in the energy policy and so on) also contribute to explain this lack of efficacy.

The results have several implications for policy making and research. Policy-makers should pay attention to the process of formation and sharing of expectations. Roadmaps reflect shared visions and strategies to accelerate system development, and thus can be instruments of transition policy [18]. In the case of roadmaps from government initiative, policy-makers should ensure a highly participatory and inclusive process. In addition, particularly if the roadmap originates from the stakeholders initiative, promises should be considered with caution given the risk of overinflated expectations. Roadmaps may also reproduce the opinions of the most powerful companies whose preferences often prevail in the negotiation process. Thus, gathering information on the process of roadmapping (e.g. participation), as well as confronting the chosen strategy with alternative technological paths, is highly recommended. Finally, policy makers should keep in mind that intervention has a typical latency of 5-10 years to see the technology response, as observed in the case of the German energy transition [78].

Future research should investigate in more detail the channels through which roadmaps influence other innovation processes. This might require a more in-detailed analysis of the process of elaboration of the roadmaps (e.g. degree of inclusiveness). For example, with more data on investments, installations and production it would be possible, in the future, to relate the quality of the roadmaps to the structuration and development of the innovation system around floating offshore wind. This would allow us to understand the extent to which the development of the floating offshore industry was driven by the roadmaps and national plans (and how) or by dominant trajectories and fortuitous events. In addition, directly inquiring the actors involved would provide insights into the underlying nature of legitimation and guidance, as well as the impact of these processes on both the evolution of expectations and the performance of the other innovation activities.

\section{Acknowledgments}

We thank the participants in the 6th International Sustainability Transitions Conference in 2015, and in the seminars in the National Laboratory of Energy and Geology (LNEG) and in Harvard Kennedy School for useful comments. The research on which this article is based was supported by a post-doctoral grant (ref. SFRH/BPD/91183/2012) and by a project (ref. PTDC/GES-OUT/30559/2017) both funded by Fundação para a Ciência e a Tecnologia (FCT). No conflict of interests to declare. 


\section{References}

[1] Abernathy WJ, Utterback JM. Patterns of industrial innovation. Technol Rev 1978;64(7):254-228.

[2] Taylor M, Taylor A. The technology life cycle: Conceptualization and managerial implications. Int J Prod Econ 2012;140(1):541-553.

[3] Huenteler J, Schmidt T, Ossenbrink J, Hoffmann V. Technology life-cycles in the energy sector - technological characteristics and the role of deployment for innovation. Technol Forecast Soc Change 2016;104:102-121.

[4] Van de Ven AH, Garud R. Innovation and Industry Development: The Case of Cochlear Implants. Res Technol Innov Manage Policy 1993;5: 1-46.

[5] Dosi G, Nelson RR. Technical change and industrial dynamics as evolutionary processes. In: Hall BW, Rosenberg N, editors. Handbook of the Economics of Innovation, North-Holland; 2010; 1, p.51-127.

[6] Markard J. The life cycle of technological innovation systems. Technol Forecast Soc Change 2018; https://doi.org/10.1016/j.techfore.2018.07.045.

[7] Winter SG. Scaling heuristics shape technology! Should economic theory take notice?. Ind Corp Change 2008;17(3):513-531.

[8] Wilson C. Up-scaling, formative phases, and learning in the historical diffusion of energy technologies. Energy Policy 2012;50:81-94.

[9] IPCC. Summary for Policymakers in Climate Change 2014: Mitigation of Climate Change. In: Edenhofer O, et al, editors. Contribution of Working Group III to the Fifth Assessment Report of the Intergovernmental Panel on Climate Change. Cambridge Univ. Press; 2014.

[10] Firestone J, Archer CL, Gardner MP, Madsen JA, Prasad AK, Veron DE. Opinion: The time has come for offshore wind power in the United States. Proc Natl Acad Sci 2015;112(39):11985-11988.

[11] European Commission. Energy -- Action needed to deliver on the potential of ocean energy by 2020 and beyond. Commission Staff Working Document Impact Assessment, Communication from the Commission to the European Parliament, the Council, the European Economic and Social Committee and the Committee of the Regions Ocean. SWD(2014) 13 final. Brussels; January 2014.

[12] Wieczorek AJ, Hekkert MP, Coenen L, Harmsen R. Broadening the national focus in technological innovation system analysis: The case of offshore wind. Environ Innov Soc Transit 2015;14:128-148.

[13] Wieczorek AJ, Negro SO, Harmsen R, Heimeriks GJ, Luo L, Hekkert, MP. A review of the European offshore wind innovation system. Renewable Sustain Energy Rev 2013;26:294-306.

[14] Markard J, Raven R, Truffer B. Sustainability transitions: An emerging field of research and its prospects. Res Policy 2012;41(6):955-967. 
[15] Carlsson B, Stankiewicz R. On the nature, function and composition of technological systems. J Evol Econ 1991;1(2):93-118.

[16] Aldrich HE, Fiol CM. Fools rush in? The institutional context of industry creation. Acad Manage Rev 1994;19:645-70.

[17] Negro SO, Alkemade F, Hekkert MP. Why does renewable energy diffuse so slowly? A review of innovation system problems. Renewable Sustain Energy Rev 2012;16(6):3836-3846.

[18] McDowall W. Technology roadmaps for transition management: The case of hydrogen energy. Technol Forecast Soc Change 2012;79:530-542.

[19] Phaal R, Farrukh C, Probert D. Technology roadmapping-A planning framework for evolution and revolution. Technol Forecast Soc Change 2004;71:5-26.

[20] Phaal R, O'Sullivan E, Routley M, Ford S, Probert D. A framework for mapping industrial emergence. Technol Forecast Soc Change 2011;78:217-230.

[21] Borup M, Klitkou A, Andersen MM, Hain DS, Lindgaard Christensen J, Rennings K. Indicators of energy innovation systems and their dynamics - a review of current practice and research in the field: Radar report. EIS; 2013.

[22] Amer M, Daim TU. Application of technology roadmaps for renewable energy sector, Technol Forecast Soc Change 2010;77:1355-1370.

[23] Van de Ven AH. The innovation journey: you can't control it, but you can learn to maneuver it. Innovation 2017:1-4.

[24] Rip A. The Context of Innovation Journeys. Creativity Innovation Management 2012;21(2):158-70.

[25] Geels FW. Regime Resistance against Low-Carbon Transitions: Introducing Politics and Power into the Multi-Level Perspective. Theory Cult Soc 2014;31(5):21-40.

[26] Bergek A, Jacobsson S, Carlsson B, Lindmark S, Rickne A. Analyzing the functional dynamics of technological innovation systems: A scheme of analysis. Res Policy 2008;37(3):407-429.

[27] Hekkert MP, Suurs RA, Negro SO, Kuhlmann S, Smits RE. Functions of innovation systems: A new approach for analysing technological change. Technol Forecast Soc Change 2007;74(4):413-432.

[28] Jacobsson S, Bergek A. Innovation system analyses and sustainability transitions: Contributions and suggestions for research. Environ Innov Soc Transit 2011;1(1):41-57.

[29] Markard J, Truffer B. Technological innovation systems and the multi-level perspective: Towards an integrated framework. Res Policy 2008;37(4):596-615.

[30] Bergek A, Jacobsson S, Sandén BA. 'Legitimation'and 'development of positive externalities': two key processes in the formation phase of technological innovation systems. Technol Anal Strategic Manage 2008;20(5):575-592.

[31] North DC. Institutions, Institutional Change and Economic Performance. Cambridge University Press; 1990. 
[32] Borrás S, Edquist C. Institutions and Regulations in Innovation Systems: Effects, Problems and Innovation Policy Design (No. 2014/29). Lund University, CIRCLE-Center for Innovation, Research and Competences in the Learning Economy; 2014.

[33] Von Hippel E. Open user innovation. In: Hall BW, Rosenberg N, editors. Handbook of the Economics of Innovation, North-Holland; 2010; 1, p.411-427.

[34] Borup M, Brown N, Konrad K, Van Lente $\mathrm{H}$. The sociology of expectations in science and technology. Technol Anal Strategic Manage 2006;18:285-298.

[35] Markard J, Wirth S, Truffer B. Institutional dynamics and technology legitimacy-A framework and a case study on biogas technology. Res Policy 2016;45(1):330-344.

[36] Zimmerman MA, Zeitz GJF. Beyond survival: achieving new venture growth by building legitimacy. Acad Manage Rev 2002;27:414-431.

[37] Hekkert MP, Negro SO. Functions of innovation systems as a framework to understand sustainable technological change: Empirical evidence for earlier claims. Technol Forecast Soc Change 2009;76(4):584-594.

[38] Suurs RA, Hekkert MP, Smits RE. Understanding the build-up of a technological innovation system around hydrogen and fuel cell technologies. Int J Hydrogen Energy 2009;34(24):96399654.

[39] Bergek A, Hekkert M, Jacobsson S, Markard J, Sandén B, Truffer B. Technological innovation systems in contexts: Conceptualizing contextual structures and interaction dynamics. Environ Innov Soc Transit 2015;16: 51-64.

[40] IEA Energy Technology Roadmaps, A Guide to Development and Implementation, 2014 Edition. OECD/International Energy Agency; 2014.

[41] Smith A, Stirling A, Berkhout F. The governance of sustainable socio-technical transitions. Res Policy 2005;34(10):1491-1510.

[42] Nemet G, Zipperer V, Kraus, M. The valley of death, the technology pork barrel, and public support for large demonstration projects. Energy Policy 2018;119:154-167.

[43] Mankins JC. Technology readiness assessments: A retrospective. Acta Astronautica 2009;65(9-10):1216-1223.

[44] Frenken K, Leydesdorff L. Scaling trajectories in civil aircraft (1913-1997). Res Policy 2000;29(3):331-348.

[45] Davies A, Hobday M. The Business of Projects: Managing Innovation in Complex Products and Systems. Cambridge University Press; 2005.

[46] Markard J, Hekkert M. Technological innovation systems and sectoral change: towards a TIS based transition framework. In: Proceedings of the International Sustainability Transitions Conference (IST). Zurich; June 2013.

[47] Markard J, Hoffmann V. Analysis of complementarities: Framework and examples from the energy transition. Technol Forecast Soc Change 2016;111:63-75.

[48] Jacobsson S, Lauber V. The politics and policy of energy system transformation-explaining the German diffusion of renewable energy technology. Energy Policy 2006;34(3):256-276. 
[49] Grubler A, Aguayo F, Gallagher K, Hekkert M, Jiang K, Mytelka L, Neij L, Nemet G, Wilson C. Chapter 24 - Policies for the Energy Technology Innovation System (ETIS). In Global Energy Assessment - Toward a Sustainable Future, Cambridge University Press, Cambridge, UK and New York, NY, USA and the International Institute for Applied Systems Analysis, Laxenburg, Austria; 2012:1665-1744.

[50] Jacobsson S, Karltorp K. Mechanisms blocking the dynamics of the European offshore wind energy innovation system-Challenges for policy intervention. Energy Policy;2013;63:1182-1195.

[51] Suchman MC. Managing legitimacy: Strategic and institutional approaches. Acad Manage Rev 1995;20(3).571-610.

[52] Geels FW, Verhees B. Cultural legitimacy and framing struggles in innovation journeys: a cultural-performative perspective and a case study of Dutch nuclear energy (1945-1986). Technol Forecast Soc Change 2011;78(6):910-930.

[53] Wüstemeyer C, Madlener R, Bunn DW. A stakeholder analysis of divergent supply-chain trends for the European onshore and offshore wind installations. Energy Policy 2015;80:36-44.

[54] Rodrigues S, Restrepo C, Kontos E, Pinto RT, Bauer P. Trends of offshore wind projects. Renewable Sustain Energy Rev 2015;49: 1114-1135.

[55] Green R, Vasilakos N. The economics of offshore wind. Energy Policy 2011;39(2):496-502.

[56] Kern F, Verhees B, Raven R, Smith A. Empowering sustainable niches: Comparing UK and Dutch offshore wind developments. Technol Forecast Soc Change 2015;100:344-355.

[57] Bento N, Fontes M. Direction and legitimation in system upscaling-planification of floating offshore wind. Working Papers DINÂMIA'CET; WP n.o 2017/01; ISCTE-IUL; 2017.

[58] JWPA. Target \& roadmap for Japanese wind power. The Japanese Wind Power Association, http://jwpa.jp/pdf/20140729_GRE2014_00995_TargetRoadmapforJapaneseWindpower.pdf; 2014 [accessed 28 July 2018].

[59] EDPR. Offshore Wind Development. October; 2014.

[60] OTEO. Roadmap Tecnológico OTEO. Observatório Tecnológico para as Energias Offshore, INEGI, WavEC, Energyin, Porto; 2014.

[61] DECC. UK Renewable Energy Roadmap Update 2013. Department of Energy \& Climate Change,

https://assets.publishing.service.gov.uk/government/uploads/system/uploads/attachment_da ta/file/255182/UK_Renewable_Energy_Roadmap_-_5_November__FINAL_DOCUMENT_FOR_PUBLICATIO__.pdf; 2013 [accessed 28 July 2018].

[62] HM Government. Offshore Wind Industrial Strategy - Business and Government Action, https://assets.publishing.service.gov.uk/government/uploads/system/uploads/attachment_da ta/file/243987/bis-13-1092-offshore-wind-industrial-strategy.pdf; 2013[accessed 28 July 2018].

[63] Boye H, Caquot E, Clement P, de La Cochetiere L, Nataf JM, Sergent P. Rapport de la mission d'étude sur les énergies marines renouvelables. Ministère de l'écologie, du développement durable et de l'énergie, Paris ; 2013. 
[64] DOE (2011). A National Offshore Wind Strategy: Creating an Offshore Wind Energy Industry in the United States. U.S. Department of Energy, U.S. Department of the Interior, DOE/EE-0798, February 7,

https://www1.eere.energy.gov/wind/pdfs/national_offshore_wind_strategy.pdf; 2011 [accessed 28 July 2018].

[65] DETI. Offshore Renewable Energy Strategic Action Plan 2012-2020. Department of Enterprise, Trade and Investment, March, Belfast, https://www.economyni.gov.uk/publications/offshore-renewable-energy-strategic-plan-oresap-2012-2020; 2012 [accessed 28 July 2018].

[66] DECC. UK Renewable Energy Roadmap. Department of Energy \& Climate Change, July, London,

https://assets.publishing.service.gov.uk/government/uploads/system/uploads/attachment_da ta/file/48128/2167-uk-renewable-energy-roadmap.pdf; 2011 [accessed 28 July 2018].

[67] Norwegian Ministry of Petroleum and Energy. C Concerning an Act on Offshore Renewable Energy Production (the Offshore Energy Act). Summary in English: Proposition No. 107(2008-2009) to the Storting; 2009. https://www.regjeringen.no/contentassets/21abe2eb6e604475ad7f179812da6583/engb/pdfs/otp200820090107000en_pdfs.pdf; 2009 [accessed 28 July 2018].

[68] EWEA. Deep Water The next step for offshore wind energy. www.ewea.org/report/deepwater; 2013 [accessed 28 July 2018].

[69] FOWIND. Offshore Wind Policy and Market Assessment - A Global Outlook. The Facilitating Offshore Wind in India project, GWEC, DNV GL, European Union, www.fowind.in; 2014 [accessed 1 August 2015].

[70] IEA. China Wind Energy Development Roadmap 2050. IEA/OECD, Paris; 2011.

[72] Smith A, Stehly T, Musial W. 2014-2015 offshore wind technologies market report (No. NREL/TP--5000-64283). National Renewable Energy Lab.(NREL); Golden, CO; 2015.

[73] DOE. A New Era for Wind Power in the United States. Technical report. US Department of Energy; Washington, DC; 2015.

[74] IEA. Offshore Wind Outlook. World Energy Outlook Series, OECD/IEA, Paris; 2018.

[75] WindEurope. Offshore Wind in Europe: Key Trends and Statistics 2017, WindEurope, Brussels, https://windeurope.org/wp-content/uploads/files/aboutwind/statistics/WindEurope-Annual-Offshore-Statistics-2017.pdf; 2018 [accessed 28 July 2018].

[76] NREL. Offshore Wind Energy Resource Assessment for the United States, NREL, Boulder, Colorado, National Renewable Energy Laboratory, www.nrel.gov/docs/fy16osti/66599.pdf; 2016 [accessed 28 July 2018].

[77] Li, J. et al. China Wind Energy Outlook, China Renewable Energy Industry Association, Beijing; 2012.

[78] Markard J. The next phase of the energy transition and its implications for research and policy. Nature Energy 2018: 1. 
[79] EWEA. The European offshore wind industry - key trends and statistics 2014, http://www.ewea.org/fileadmin/files/library/publications/statistics/EWEA-EuropeanOffshore-Statistics-2014.pdf; 2015 [accessed 28 July 2018].

[80] WindEurope. Offshore Wind in Europe: Key Trends and Statistics 2017, WindEurope, Brussels, https://windeurope.org/wp-content/uploads/files/aboutwind/statistics/WindEurope-Annual-Offshore-Statistics-2016.pdf; 2017 [accessed 28 July 2018].

[81] Battaglia B, Gorintin F, Mouslim H. Floating offshore wind market outlook. In: Proceedings of the Marine Energy Week; Bilbao, 20-24 April, http://www.bilbaomarinenergy.com/CMSPages/GetFile. aspx?guid=20cf7133-c0e8-439e-98b9691e10f156cd; 2015 [accessed 5 August 2015].

[82] European Wind Energy Technology Platform. Strategic Research Agenda / Market Deployment Strategy. Brussels; March 2014.

[83] The Crown Estate. Offshore Wind Cost Reduction Pathways Study. http://www.thecrownestate.co.uk/media/5493/ei-offshore-wind-cost-reduction-pathwaysstudy.pdf; 2012 [accessed 10 August 2015].

[84] 4COffshore, http://www.4coffshore.com; 2015.

[85] Main(e). Floating Offshore Wind Foundations: Industry Consortia and Projects in the United States, Europe, and Japan. Maine International Consulting, http://www.mainewindindustry.com/node/10432; 2013 [accessed 8 August 2015].

[86] IRENA. Reneable Energy Technologies: Cost Analysis Series. Volume 1: power Sector, Issue 5/5. Working Paper, Abu Dhabi; 2012.

[87] Normann HE. The role of politics in sustainable transitions: The rise and decline of offshore wind in Norway. Environ Innov Soc Transit 2015;15:180-193.

[88] Higgins P, Foley A. The evolution of offshore wind power in the United Kingdom. Renewable Sustain Energy Rev 2014;37:599-612.

[89] Veum K., Cameron L., Huerta Hernandes D., Korpås M. Roadmap to the deployment of offshore wind energy in the Central and Southern North Sea (2020-2030); 2011.

[90] Mizuno E. Overview of wind energy policy and development in Japan. Renewable Sustain Energy Rev 2014;40:999-1018.

[91] Hoppmann J, Huenteler J, Girod B. Compulsive policy-making - The evolution of the German feed-in tariff system for solar photovoltaic power. Res Policy 2014;43:1422-1441. 


\section{APPENDIX 1. FRAMEWORK TO ANALYSE ROADMAPS}

\section{ROADMAP FEATURES}

Type of document (Roadmap; National Plan...)

Focus (Floating offshore; Offshore wind; Ocean energies, etc.)

Initiative (government, stakeholders' coalitions, companies, etc.)

Indicate who participated in formulation?

Date (start \& publication if available)

Follow-up procedure?

\section{CONTEXT}

Identify main national policies concerning energy and climate change? (including renewable energies)

Identify electricity market reform as a driver?

Estimate benefits? (resource potential, job creation, etc.)

Define (contextual) obstacles to deep offshore wind? Strategy to address them?

\section{FUNCTIONS}

\section{Influence on the direction of search}

Document helps networks of actors and institutions improving the visibility of the offshore wind development? How?

Set technology development goals and time frame?

Define steps? ( $\mathrm{Y} / \mathrm{N})$ Establish goals or milestones for different steps?

Present future outlooks of offshore wind energy against competing technologies?

Preference for domestic manufacturing (explicit)?

\section{Legitimacy}

Did roadmap formulation process and proposals contribute to increase legitimation? In particular, by helping in the formation of a vision and expectations?

Is the regulation (e.g. codes and standards) sufficiently developed and aligned with the needs of technology up-scaling?

How much resistance is faced by the technology before and after receiving permit?

\section{Knowledge development}

Are there gaps in (national) knowledge and competences needed for the growth and acceleration of the innovation system?

Are the number and diversity of actors involved in knowledge development enough?

\section{Entrepreneurial experimentation}

To what extent did technology start to be up-scaled?

Are there enough actors active in the emergence and up-scaling?

Are the actual plans of experimentation adequate?

\section{Resource mobilization}

Is financial capital (public and private) sufficiently available?

Is there enough human capital in number and diversity?

\section{Materialization}

Are there already plants for equipment production?

Is the physical infrastructure already (or in a timely manner) in place? 


\section{Market formation}

Are market prospects sufficient to sustain innovation and entrepreneurial experimentation? Is the size of the internal market sufficient to develop floating offshore wind?

\section{STRUCTURE DEVELOPMENT}

\section{Technology}

Sepecify technological specific goals? (efficiency, reliability, etc.) Identify development phase of system? (Phaal's framework) What type of barriers are preventing a more rapid technology up-scaling? Costs? Low standardization?

\section{Actors}

Which actors are presented as necessary to accelerate process/achieve goals?

- Already in the system?

- Needing to be involved (why?)

Refer to the involvement of society: e.g. social acceptance and participation?

Identify key actors? Explain the roles to be played?

Identify leadership?

System dimension?

\section{Networks}

Identify value chain that needs to be built?

Types of alliances that are referred as needing to be established: within the system; with actors external to the system; with other systems? (why?)

Nature of networks: business; research \& technology; intermediation; policy lobby; (or mixed) Refer to network's coordination? (e.g. actors with central role in networks)

Explicitly refer to the need to align actors?

\section{Institutions}

Have policy makers been involved in the process of development of roadmap/plan (as participants; only consulted over proposals)?

Indicate policies that need to be introduced? (when; how if not government-led)

Refer to regulation that needs to be set up (technology specific; complementary - e.g. ocean energy/marine spatial planning)?

Refer to the need to establish new standards? How? 